\title{
Lifestyle, efficiency and limits: modelling transport energy and emissions using a socio-technical approach
}

\author{
Christian Brand $($ D $\cdot$ Jillian Anable $\cdot$ Craig Morton
}

Received: 26 October 2017 / Accepted: 25 April 2018/Published online: 8 May 2018

(C) The Author(s) 2018

\begin{abstract}
It is well-known that societal energy consumption and pollutant emissions from transport are influenced not only by technical efficiency, mode choice and the carbon/pollutant content of energy but also by lifestyle choices and socio-cultural factors. However, only a few attempts have been made to integrate all of these insights into systems models of future transport energy demand or even scenario analysis. This paper addresses this gap in research and practice by presenting the development and use of quantitative scenarios using an integrated transport-energy-environment systems model to explore four contrasting futures for Scotland that compare transport-related 'lifestyle' changes and socio-cultural factors against a transition pathway focussing on transport electrification and the phasing out of conventionally fuelled vehicles using a socio-technical approach. We found that radical demand and supply strategies can have important synergies and trade-offs between reducing life
\end{abstract}

\footnotetext{
C. Brand $(\square)$

University of Oxford and UK Energy Research Centre, South

Parks Road, Oxford OX1 3QY, UK

e-mail: christian.brand@ouce.ox.ac.uk

\section{J. Anable}

Institute for Transport Studies, University of Leeds and UK Energy Research Centre, 34-40 University Road, Leeds LS2 9JT, UK

e-mail: J.L.Anable@leeds.ac.uk

C. Morton

Transport Studies Group, Loughborough University, Sir Frank Gibb Building, Loughborough LE11 3TU, UK

e-mail: C.Morton@lboro.ac.uk
}

cycle greenhouse gas and air quality emissions. Lifestyle change alone can have a comparable and earlier effect on transport carbon and air quality emissions than a transition to EVs with no lifestyle change. Yet, the detailed modelling of four contrasting futures suggests that both strategies have limits to meeting legislated carbon budgets, which may only be achieved with a combined strategy of radical change in travel patterns, mode and vehicle choice, vehicle occupancy and on-road driving behaviour with high electrification and phasing out of conventional petrol and diesel road vehicles. The newfound urgency of 'cleaning up our act' since the Paris Agreement and Dieselgate scandal suggests that we cannot just wait for the 'technology fix'.

Keywords Transportation energy · Transport systems modelling $\cdot$ Emissions modelling $\cdot$ Socio-technical approach · Lifestyle change

\section{Introduction}

The outcomes of the 2015 Paris Agreement (United Nations 2015) and the US 'Dieselgate' emissions

\footnotetext{
${ }^{1}$ While there is no official definition of the term 'Dieselgate', it has become synonymous with the use by the Volkswagen Group of a 'defeat device' that detects when a diesel car is undergoing an official emission tests and optimises engine performance to minimise air pollutant emissions to meet stringent emissions regulations. The device is only activated during the official test. Vehicles by other manufacturers have also been shown to exceed emissions in real-world driving conditions; however, there has been no evidence of 'defeat devices' being used outside Volkswagen.
} 
scandal have prompted policy makers, regulators and industry to re-evaluate strategies to meet climate change mitigation and air quality goals. A wide range of supply and demand policies have been proposed at both national (e.g. graded purchase taxes favouring electric vehicles, scrappage rebates for replacing diesel vehicles with electric vehicles), subnational (e.g. eco-driving programmes) and local levels (e.g. phasing out or banning of diesel/petrol vehicles, air quality driven speed limits). However, policy implementation has been lagging aspiration, and buyers have so far responded rather slowly and patchily, in many parts of the world. There are exceptions, of course, exemplified by the recent dip in diesel car sales in the UK (a 6\% change in market share from diesel to petrol and plug-in cars between 2016 and 2017), which suggests that change can happen faster than we might expect and for reasons beyond price and regulation (e.g. anti-diesel rhetoric, change in attitudes, delayed purchasing decisions due to market uncertainty) (SMMT 2018).

It is well-known that transport energy consumption and related pollutant emissions are influenced not only by technical efficiency, mode choice, activity levels and the carbon/pollutant content of energy (EEA 2011; Yang et al. 2009), but also by the way we live (or 'lifestyles"2), socio-cultural factors (e.g. expenditure patterns, localism, multiple car ownership, (un)acceptability of air travel, social norms, habits and the ageing population) and, crucially, by changes in the number of and composition of the population. As only few attempts have been made to apply these insights in models of future transport energy demand (Anable et al. 2012; Chitnis and Hunt 2012; Köhler et al. 2009; Skippon et al. 2016; Weber and Perrels 2000), there is a methodological gap between the identified importance of these factors for transport energy systems and quantitative modelling frameworks.

Electrification of the passenger vehicle and light goods vehicle fleets is a key strategy and viewed as necessary to achieve deep decarbonisation and cleaning up of the transport sector (AEA Technology 2009; CCC 2015; IEA 2011, 2015a; Köhler et al. 2009; OLEV 2013; Sims et al. 2014), but there are concerns that the pace and extent implied by the underlying modelling studies are problematic and that assessment of consumer, social and market factors have been relatively

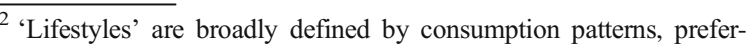
ences, use of time and space, social values and norms, and public acceptance.
}

neglected (Anable et al. 2012; Graham-Rowe et al. 2012; Leinert et al. 2013; Tran et al. 2012). In the United Kingdom (UK; national) and Scotland (subnational), for example, the policy focus on vehicle technology reflects other global transport modelling exercises that depend upon between 40 and $90 \%$ market penetrations of technologies such as plug-in hybrid electric (PHEV) and full battery electric vehicles (BEV) between 2030 and 2050 (CCC 2016; IEA 2015b; Scottish Government 2013c). Although scenario exercises such as these are used to explore the potential carbon emission reduction from a vehicle fleet evolution towards low carbon vehicle technologies, the main risk is that the full potential and necessary contribution of lifestyle change, consumption behaviour and the important role of user attitudes and perceptions are often overlooked by decision makers. Other than changes in cost or time preferences required to facilitate the uptake of low carbon vehicles (Daly et al. 2014; Dodds and McDowall 2014), many of these scenario exercises treat other societal developments that impact on transport as external to the decision making process (Geels et al. 2017).

Scotland is an interesting case study as it has highly ambitious and legislated climate change (Scottish Government 2013c, 2017) and air quality (Scottish Government 2015) targets, and a sub-national governance structure (Anderton 2012) that allows subnational and local policies to be implemented that may go beyond UK and EU plans and policies (Melo 2016). Indeed, existing policies and plans by the Scottish Government include 'softer' demand policies (such as 'smarter choices' and car and lift sharing) and 'longterm reconfiguration of the transport sector' that are often ignored (Scottish Government 2013b, c, 2017).

This paper addresses this gap in research and practice by presenting the development and use of quantitative scenarios using an integrated transport-energyenvironment systems model to explore four contrasting futures that compare transport-related lifestyle change with a low-carbon technology-focussed transition pathway using a socio-technical approach. A relatively ambitious techno-economic-focussed scenario is evaluated against one in which lifestyle change is shaped by concerns about the way we travel, how much this impacts on energy use, the environment and our well-being so that transport energy and emissions are at significantly lower levels by 2050 than in the other pathways depicting existing policies and plans. By doing so, this paper aims to answer the questions: How do we go 
further (beyond low cost technologies and minimal behavioural change)? How do we go faster (increasing the pace of change and innovation, and more ambitious policy)? Are there synergies and trade-offs to be made (demand vs supply, climate change vs air quality)? If the goals of the Paris Agreement ${ }^{3}$ and the targets of national and subnational legislation on climate change and air quality are to be met, more fundamental demand side changes are necessary (Creutzig et al. 2018). The paper thus challenges policy, practice and business to consider the dominant focus on technical solutions for transport.

\section{Approach, methods and data}

\section{Study approach}

To achieve the above objectives, we first developed a Scottish version of the UK Transport Carbon Model (UKTCM), which is a previously developed transportenergy-environment system modelling framework that has been applied in a number of scenario (Anable et al. 2012; Brand et al. 2017) and policy (Brand et al. 2013) modelling studies to date. The resulting Scottish Transport Energy and Air pollution Model (STEAM) is a disaggregated, bottom-up modelling framework of the Scottish transport-energy-environment system, built around a set of exogenous scenarios of socio-economic, socio-technical and political developments. The modelling framework is briefly summarised in the next section, with further details published elsewhere (Brand 2010; Brand et al. 2012).

In a second step, STEAM was applied in a Scottish case study to explore and compare the travel, energy use and emissions impacts of alternative scenarios of radical behaviour change vs. a relatively ambitious electrification pathway using a socio-technical approach to scenario modelling. This builds on a previous study by Anable et al. (2012), with a new geographical focus and new scenario variants and analysis informed by the more recent literature including Geels et al. (2017) and Creutzig et al. (2018). We outline the core methods next before spending some time on describing the scenario narratives and assumptions.

\footnotetext{
3 The Paris Agreement established a near universal covenant amongst world leaders to take action to hold "the increase in ... temperature to well below $2{ }^{\circ} \mathrm{C} \ldots$ and to pursue efforts to limit the temperature increase to $1.5^{\circ} \mathrm{C}$ ".
}

\section{Outline of the core methods}

STEAM integrates a transport demand simulation model, household car ownership model, consumer segmented vehicle choice model, vehicle stock evolution model and vehicle and fuel life cycle emissions model in a single scenario modelling framework. The model projects transport demand and supply, for all passenger and freight modes of transport, and calculates the corresponding energy use, life cycle emissions and environmental impacts year-by-year up to 2100 (NB: the time horizon for this study was 2012 to 2050).

A detailed description is beyond the scope of this paper, and most of the methods have been published elsewhere (Brand 2016; Brand et al. 2017, 2012). Briefly, the transport demand model simulates passenger travel demand as a function of key travel indicators structured around data obtained from the UK National Travel Survey (Department for Transport 2016), including the average number of trips and average distance travelled per person per year. These were further disaggregated by seven main trip purposes (commuting, business, long distance leisure, local leisure, school/education, shopping, other), eight trip lengths (under 1, 1-2, 2-5, 5-10, 10-25, 25-50, 50-100 and more than $100 \mathrm{mi}$ ) and 12 modes of passenger transport (walk, bicycle, car/van driver, car/van passenger, motorcycle, local bus, coach, rail and underground, other private, taxi, domestic air, other public). International air travel is modelled separately as a function of income (GDP/capita), population and supply and policy costs (Brand 2010; Brand et al. 2012). Freight demand is simulated as a function economic activity (GDP/capita) and population, with reference demand elasticities taken from a RAND Europe study (Dunkerley et al. 2014).

The vehicle stock model provides projections of how vehicle technologies evolve over time for 770 vehicle technology categories, including $283 \mathrm{car}$ technologies such as increasingly efficient gasoline internal combustion vehicles (ICV), battery electric vehicles (BEV) and plug-in hybrid electric vehicles (PHEV). The car fleet model is the most detailed, including market (private vs. fleet/company, three car sizes/segments) and consumer segmentation (four private and two fleet/company segments). New vehicle choice is modelled using a hybrid discrete choice and consumer segmentation model, as described in Brand et al. (2017). Road freight vehicles come in three sizes/ classes: vans (up to 7.5 t), 'medium' trucks (typical 12-24t non-articulated truck, intercity and intra-city distribution) and 'heavy' trucks (32-40-t articulated truck, long distance 
haulage). This is obviously an over-simplification of the distribution and haulage vehicle fleets, but deemed appropriate for a strategic modelling tool that captures the main fleet categories. Van and truck propulsion system options include diesel ICV, diesel PHEV, BEV, compressed natural gas $(\mathrm{CNG}) \mathrm{ICV}$ and hydrogen $\left(\mathrm{H}_{2}\right)$ fuel cell electric vehicle (FCEV).

The energy and emissions model calculates fuel and energy consumption as well as pollutant emissions for eight direct pollutants (carbon dioxide, $\mathrm{CO}_{2}$, methane, $\mathrm{CH}_{4}$, carbon monoxide, $\mathrm{CO}$, sulphur dioxide, $\mathrm{SO}_{2}$, nitrogen oxides, $\mathrm{NO}_{\mathrm{X}}$, non-methane volatile organic compounds, NMVOC, and particulates, PM) arising from the operation of vehicles by using the established emissions factor method underlying HBEFA (INFRAS 2009) and COPERT (EEA 2000, 2012). This is most detailed for road vehicles, where emissions are based on averagespeed emissions-curves for 'hot' emissions as well as excess emissions from 'cold starts' (ibid.). It allows to model the combined effects of different fleet compositions, different sets of emission factors, traffic characteristics, cold starts, fuel quality and driver behaviour.

Finally, the life cycle inventory model calculates energy use and emissions (including primary energy and land use) for the manufacture, maintenance and disposal of vehicles; the construction, maintenance, and disposal of infrastructure; and the supply of energy (fuels). This adds 18 unregulated air pollutants and land use change indicators. The environmental impacts assessment model then provides an assessment of the damage caused by calculating impact indicators (e.g. global warming potential) and external costs (e.g. social cost of carbon, or damage costs to human health).

\section{Scenario development: the case of Scotland}

We first developed storylines and then quantified these to yield four core scenarios, as shown in Fig. 1 and described further in Table 1.

\section{Reference pathway (REF)—-key data and assumptions}

STEAM was calibrated to Scottish national statistics for the year 2012 (DfT 2014). We obtained Special Licence Access to the National Travel Survey dataset (Department for Transport 2016) and used SPSS v23 to derive average trip rates, distance travelled and mode splits for Scotland. Due to the smaller sample size of the Scottish sample, the travel demand data were pooled over the years 2010, 2011 and 2012. The 'Reference' scenario (REF) broadly describes a projection of transport demand, supply, energy use and emissions as if there were no changes to transport and energy policy beyond current policy. It was modelled using STEAM based on exogenous assumptions and projections of socio-demographic (incl. demand effects of an ageing of the population), economic, technological and (firm and committed) policy developments, including the recently simplified vehicle road tax and relatively complex $\mathrm{CO}_{2}$-graded company car tax regimes. Economic growth data up to 2015 were based on government figures. Future GDP/capita growth was assumed to average $1.35 \%$ p.a. up to 2050. Transport demand projections were modelled based on no changes in trip patterns ${ }^{4}$ (i.e. trips and distance travelled per person p.a., and mode split) apart from lower commuting levels due to an ageing population, and average demand elasticities (of GDP/capita, population and generalised cost) for international air and freight transport (Dunkerley et al. 2014; Sims et al. 2014). Fuel price and retail electricity price projections were based on 2014 UK Government forecasts (DECC 2014). Annual road tax and road fuel duties were assumed to remain constant at 2017 levels.

Pre-tax vehicle purchase costs were kept constant over time for established technologies and gradually decreased for advanced and future technologies, thus exogenously simulating improvements in production costs, economies of scale and market push by manufacturers. ${ }^{5}$ For example, average purchase prices for BEV cars were assumed to decrease by $2.8 \%$ pa from 2015 to 2020 , by $1.6 \%$ pa until 2030 and $0.6 \%$ pa until 2050 , based on projected BEV battery cost reductions (Nykvist and Nilsson 2015). The Reference scenario further assumed gradual improvements in specific fuel consumption and tailpipe $\mathrm{CO}_{2}$ emissions per distance travelled (see Supplementary Materials in Brand et al. 2017). The rates of improvement were based on technological innovation driven entirely by market competition, not on policy or regulatory push. ${ }^{6}$ Fuel

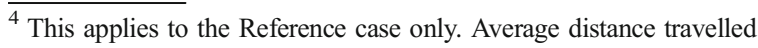
varies by propulsion technology (e.g. diesel cars travel further per year than petrol or EV cars, based on national statistics).

${ }^{5}$ The assumption that alternative technologies improve (cost, energy and environmental performance, consumer preferences) at a faster rate over time applies equally to all scenarios modelled here, not just the reference scenario.

${ }^{6}$ This implies that the EU mandatory agreement on new car $\mathrm{CO}_{2}$ emissions would not be met. However, separating innovation by competition and innovation by regulation/policy push is slightly arbitrary here, as the effects are never easy to untangle.
} 
Fig. 1 Outline of the scenario modelling approach

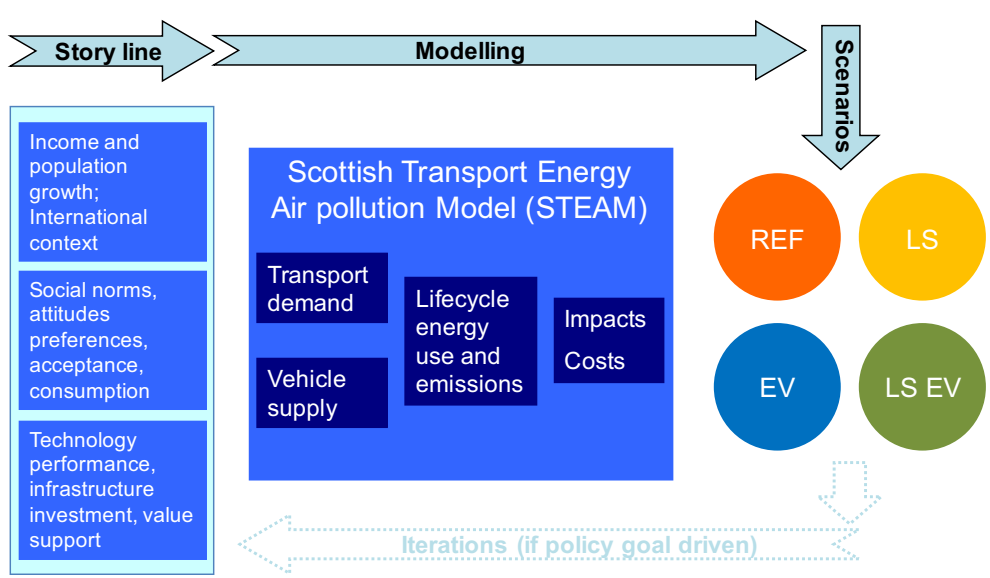

consumption and $\mathrm{CO}_{2}$ improvement rates for future car vintages were assumed to be $1.5 \%$ p.a.-a somewhat lower and more conservative rate than the average rate of $4 \%$ p.a. based on test-cycle data for all new cars between 2008 and 2013 (NB: 'real-world' improvements have been significantly lower, as shown by ICCT (2016) and others). Indirect emissions from fuel supply and vehicle manufacture, maintenance and scrappage have been updated with data from a recent UK-based review (Kay et al. 2013).

Finally, the default electricity generation mix follows central government projections (mainly natural gas, wind and nuclear-with some CCS coal and gas by 2030), implying that the carbon content of retail electricity is gradually decreasing from about $390 \mathrm{gCO}_{2} /$ $\mathrm{kWh}$ in 2015 to about $160 \mathrm{gCO}_{2} / \mathrm{kWh}$ in 2030 . In the absence of any government projections beyond 2030, we have assumed that the carbon content stays constant at this level out to 2050 .

\section{The 'lifestyle' (LS) scenario: storyline and travel demand modelling}

Most transport and energy modelling are based on principles of cost optimisation (Dodds and McDowall 2014), utility maximisation of discrete choices or on the principle that travel-time 'budgets' are fixed (Ahmed and Stopher 2014; Bates 2000). Some notable efforts have been made to model behavioural factors endogenously at the level of the wider transport-energy-climate system (Köhler et al. 2009; Pye and Daly 2015; Tattini et al. 2018; Zimmer et al. 2017). Yet, evidence relating to

Table 1 The four socio-technical scenarios for Scotland

\section{Reference (REF)}

Projection of transport demand, supply, energy use and emissions as if there were no changes to existing transport and energy policy

\section{EV Electric vehicle promotion and} petrol/diesel 'phase-out' (EV)

Pathway of 'high electrification' + phasing out of conventional oil based ICVs: range of measures incl. pricing, taxation, investment, EV infrastructure, scrappage/purchase tax on future diesel and petrol cars, changing consumer preferences

\section{Lifestyle change (LS)}

Radical change in travel patterns and mode choice leading to relatively fast transformations and new demand trajectories

\section{Combined lifestyle and EV pathway (LS EV)}

Integration of radical change in travel patterns, mode choice, high electrification and phasing out of conventional petrol and diesel road vehicles 
actual travel choices, including vehicle choice, suggests that social change is strongly influenced by concerns relating to health, quality of life, energy use and environmental implications. As such, non-price-driven behaviour (Anable 2005; Cohen et al. 2013; Li et al. 2015; Litman 2017; Schwanen et al. 2011) was deemed to be a dominant driver of energy service demand from transport in this 'lifestyle' scenario.

The lifestyle consumer, including 'fleet' or company consumers, is more aware of the whole cost of travel (including fixed or sunk costs of owning a vehicle) and the energy and emissions implications of travel choices. People become more sensitive to the rapid normative shifts which alter the bounds of socially acceptable behaviour, e.g. on 'binge flying' (Cohen et al. 2011), car choice (Barth et al. 2016) and mobility (in)justice (Mullen and Marsden 2016). Accordingly, the lifestyle scenario assumed that the focus would shift away from mobility towards accessibility of services and jobs and from speed to quality and resilience of journeys. Triggered by worsening conditions (e.g. sensitivity to congestion and air quality concerns) and catastrophic events (increased frequency of flooding and/or heatwaves), social norms promote the status of more sustainable and resilient modes of transport and demote singleoccupancy car travel, fossil fuelled vehicles, unnecessarily long distances, speeding and air travel.

More efficient, low-energy and zero energy (nonmotorised) transport systems (e.g. the use of cycling networks) replace current car-based systems running on petrol and diesel. New models of Mobility as a Service (MaaS) (Mulley 2017) and the Sharing Economy (Ritzer and Jurgenson 2010) are embraced. This includes taxi hailing mobile applications, car clubs ${ }^{7}$ and the tendency to hire a shared PHEV for longer distance travel. These are niche markets in which new vehicle technology is fostered. Information and Communication Technology (ICT: telematics, in-car instrumentation, video conferencing, smartcards, e-commerce, connected vehicles) facilitates relatively rapid behavioural change by making cost and energy use transparent to users. This transparency and enablement of responsive choices changes everything from destination choice, substitution of shopping and personal business trips by home delivery, car choice and models of 'ownership', driving style and paying for travel,

\footnotetext{
${ }^{7}$ In the UK and Scotland, Car clubs are 'pay as you go' car hire schemes known as 'Car sharing' in many other European Countries.
}

including in the freight sector. As transport and destination choices become more diverse and widely accessible, there is increasing acceptance of restrictive local policies to further accelerate change. It also becomes socially unacceptable to drive children to school. However, capacity constraints limit the pace of change so that mode shift to buses and rail will be moderated.

The new modes and digitalisation, in turn, will result in a new spatial order towards compact cities, mixed land uses and self-contained cities and regions. Average distances travelled are also reduced as distance horizons change partly from the use of cycling and walking and partly from a renewed focus on localism (Ferreira et al. 2017). Some services return to rural areas, though moderated by the ability to carry out much personal business online. The habit of frequent air travel declines as not only does it become socially unacceptable to fly short distances, but also airport capacity constraints as well as a 'frequent flyer levy' (Devlin and Bernick 2015) mean that it becomes less attractive. Weekends abroad are replaced by more domestic leisure travel, but this is increasingly carried out by shared low-carbon vehicles, rail and express coach and walking and cycling trips closer to home. As a result, car ownership is lower than in the Reference scenario. An even more radical change takes place through changes in work patterns and business travel not only fuelled by renewed emphasis on quality of life but also facilitated by increasingly sophisticated ways of substituting disproportionally impactful long commuting and business trips by digital technology. The impacts of teleworking and video conferencing are known to be complex, but recent studies have highlighted that they could be potentially important, especially when implemented with the explicit purpose of reducing transport and energy (Gross et al. 2009; Jones et al. 2018; Scottish Government 2013a).

Increased internet shopping (Çelik 2011; Morganti et al. 2014; Suel and Polak 2017) and restrictions on heavy goods vehicles, particularly in town centres, increase the use of vans, which somewhat offsets the positive effects of decongestion from fewer cars on the road. There is increased relative decoupling of road freight from economic activity due to a return to more localised sourcing (McKinnon 2007), a major shift in the pattern of consumption to services and products of higher value, the digitization of media and entertainment, and an extensive application of new transport-reducing manufacturing technologies such as 3-D printing (Birtchnell et al. 2013). There is some shift towards rail freight and passenger rail from domestic air. 
The consequences for travel patterns of these lifestyle changes were first analysed using the STEAM travel demand model, which took as its starting point the figures for current individual travel patterns based on Scottish data in the UK National Travel Survey (Department for Transport 2016). The Scottish data was analysed so as to derive figures for each journey purpose (commuting, travel in the course of work, shopping, education, local leisure, distance leisure and other) in terms of average number of trips, average distance (together producing average journey length). In addition, mode share and average occupancy were altered based on an evidence review (e.g. Cairns et al. 2004, 2008; Petrunoff et al. 2015; Scottish Government 2013a) relating to the impact of transport policies and current variation in travel patterns within and outside Scotland. The ensuing changes in trip rates, average trip lengths and mode shifts by trip length are provided in Tables 3 and 4 . Key travel indicators are summarised in Table 2.

In estimating what rate and scale of change seems reasonable, most weight was given to the existing variation in lifestyle observed in societies similar to Scotland, i.e. technologically advanced, liberal democracies. Whilst Scotland has a relatively low average population density due to vast expanses of relatively uninhabited landscape, around $80 \%$ of the population live in localities of and around the country's five largest urban areas of Glasgow, Edinburgh, Aberdeen, Dundee and Inverness. Given this predominance of urban and suburban travel, it seems reasonable to suppose that if a significant fraction of the population (say 5-10\%) somewhere in the OECD already behave in a particular way, then it is plausible for this to become a common behaviour in Scotland within the timeframe to 2050. Careful consideration and a more conservative approach was used to take account of specific climate and topographic factors with regard to Scotland, and this led to a lower level of ambition than might have been applied to cycling in particular.

Overall, the Lifestyle scenario implies neither incremental nor step changes in behaviour. It is increasingly clear that incremental changes in efficiency and behaviour will not be effective enough to deliver sustainable

Table 2 Summary results of the combined lifestyle and high EV scenario (LS EV)

\begin{tabular}{|c|c|c|c|c|}
\hline & 2012 & 2020 & 2030 & 2050 \\
\hline Average number of trips (per person per year) & 1010 & 1006 & 999 & 955 \\
\hline Average distance travelled (km per person per year) & 11,498 & 11,321 & 11,029 & 9845 \\
\hline Avg. car occupancy & 1.57 & 1.58 & 1.62 & 1.76 \\
\hline \multicolumn{5}{|l|}{ Mode split (\% distance) } \\
\hline Cars and motorcycles & $74 \%$ & $71 \%$ & $61 \%$ & $41 \%$ \\
\hline Slow modes & $3 \%$ & $4 \%$ & $8 \%$ & $17 \%$ \\
\hline Bus and rail & $14 \%$ & $15 \%$ & $19 \%$ & $28 \%$ \\
\hline Taxi/'Uber', car clubs, other private & $2 \%$ & $3 \%$ & $4 \%$ & $7 \%$ \\
\hline Domestic air & $7 \%$ & $6 \%$ & $6 \%$ & $6 \%$ \\
\hline 'On-road fuel efficiency' & $\mathrm{km}$ affected & $\mathrm{km}$ affected & $\mathrm{km}$ affected & km affected \\
\hline Cars, $8 \%$ better per $\mathrm{km}$ & $4 \%$ & $17 \%$ & $52 \%$ & $62 \%$ \\
\hline Vans, $8 \%$ better per $\mathrm{km}$ & $2 \%$ & $17 \%$ & $59 \%$ & $70 \%$ \\
\hline Trucks, $4 \%$ better per $\mathrm{km}$ & $2 \%$ & $17 \%$ & $59 \%$ & $70 \%$ \\
\hline International air demand growth (pa) & $1.2 \%$ & $0.9 \%$ & $0.5 \%$ & $0.1 \%$ \\
\hline \multirow[t]{3}{*}{ Vehicle technology choice, e.g. share of new cars by propulsion/fuel } & \multirow[t]{3}{*}{$98 \%$ ICV petrol/diesel } & $17 \% \mathrm{HEV}$ & $2 \% \mathrm{HEV}$ & $0 \% \mathrm{HEV}$ \\
\hline & & $1 \% \mathrm{BEV}$ & $13 \% \mathrm{BEV}$ & $45 \% \mathrm{BEV}$ \\
\hline & & $3 \%$ PHEV & $53 \% \mathrm{PHEV}$ & 40\% PHEV \\
\hline Direct $\mathrm{CO}_{2}$, reduction over baseline $(\mathrm{REF})$ & $\mathrm{n} / \mathrm{a}$ & $-4 \%$ & $-21 \%$ & $-47 \%$ \\
\hline Lifecycle $\mathrm{CO}_{2} \mathrm{e}$, reduction over baseline (REF) & $\mathrm{n} / \mathrm{a}$ & $-5 \%$ & $-20 \%$ & $-42 \%$ \\
\hline Cumulative lifecycle $\mathrm{CO}_{2} \mathrm{e}$ savings $\left(\mathrm{MtCO}_{2} \mathrm{e}\right)$ & $\mathrm{n} / \mathrm{a}$ & -1.9 & -17.4 & -97.2 \\
\hline Direct $\mathrm{NO}_{\mathrm{X}}$, reductions over baseline (REF) & $\mathrm{n} / \mathrm{a}$ & $-2 \%$ & $-12 \%$ & $-38 \%$ \\
\hline Direct $\mathrm{PM}_{2.5}$, reductions over baseline (REF) & $\mathrm{n} / \mathrm{a}$ & $-2 \%$ & $-9 \%$ & $-34 \%$ \\
\hline
\end{tabular}


energy systems on their own (CCC 2016; Crompton 2008; Maione et al. 2016). Instead, this Lifestyle scenario outlines far-reaching change leading to relatively fast transformations and new demand trajectories.

\section{The high electrification pathway (EV)}

This scenario combines a transformative pathway developed for the UK's Committee on Climate Change (CCC 2013, 2015). It focuses on supply measures for plug-in cars and vans as an alternative to fossil fuel vehicles combined with a purchase tax aimed at phasing out petrol/diesel vehicles (ICV, HEV but not PHEV) out of urban areas by 2030. The analysis by the CCC suggested plug-in vehicle deployment targets for 2020 and 2030 at 9 and $60 \%$, respectively. A small number of scenarios were run using STEAM in an iterative process that led to the high electrification pathway. This implied transformational change including the following: significant investment and repositioning towards ultra-low emission vehicles (ULEVs) by the main vehicle manufactures with ultra-low emission vehicles (ULEVs) being available in all car segments (e.g. 'supermini', 'large family', 'crossover') and by all major brands by 2030 ; petrol/diesel cars, vans and buses are gradually phased out through higher purchase/scrappage taxes, reinforced by low emission zones and increased parking charges in cities/towns; and Scotland-wide consumer awareness and acceptance of ULEV cars by the 2030s driven by comprehensive awareness campaigns and the 'neighbour effect' (Mau et al. 2008). In particular, the fiscal and regulatory 'sticks' are balanced by the carrots of significant investment in recharging infrastructure (home charging, fast charging stations in and beyond Scotland), reduced (perceived) recharging times, and continued and improved 'equivalent value support' (taxation, fuel duty) for ULEVs for both private and company/fleet buyers.

As for the road freight sector, diesel ICV technology prevails for much of the scenario period due to the continued non-availability of gas- and hydrogen-powered vehicles and infrastructure, and the assumed economic and performance advantage of incumbent technology over EVs for long distance haulage and distribution. As for EV trucks, while overhead power supply lines have been explored in some countries (Germany, France), their deployment may be problematic and uneconomic for a small country such as Scotland (few motorways, dense cities, no history of trolley buses).

\section{The integrated scenario (LS EV)}

This combines radical change in travel patterns, mode choice, vehicle occupancy and on-road driving behaviour (as in LS) with high electrification and phasing out of conventional petrol and diesel road vehicles (as in EV). Essentially, lower demand is met by a different modal and vehicle mix and lower carbon/energy supply.

\section{Results}

\section{Impact on travel patterns and vehicle technology}

The impact on travel patterns and vehicle technology choice can be divided into five key areas of transport energy demands: (1) changing passenger travel patterns, (2) air travel, (3) freight transport, (4) driving style and on-road fuel efficiency, and (5) vehicle technology choice.

\section{Travel patterns change considerably in the lifestyle scenarios}

In the lifestyle scenarios (LS, LS EV), the use of all noncar surface transport modes increases due to mode shift to public transport and new mobility services. The distance travelled by car as a driver or a passenger decreases by $52 \%$ by 2050 , which is a result of significant mode shifts, particularly to bus travel towards the latter part of the period $(+85 \%$ for local bus, $+260 \%$ for express coach) and cycling and walking for shorter trips (trips under $5 \mathrm{mi}$ ) in urban areas. Mode shift is combined with destination shifting, as trips are either fully removed from the system through 'virtual travel' or shorter as a result of localisation.

People increasingly use a multitude of modes in the lifestyle scenarios (Fig. 2). While in 2030, the car is still used for the majority of distance travelled as a driver or passenger $(61 \%)$, this drops to $40 \%$ by 2050 . This reflects the assumption that cars are increasingly banned or priced out of city/town centres. At the same time, cycling goes from accounting for less than $1 \%$ to more than $8 \%$ of distance travelled, mainly replacing short car trips under $5 \mathrm{mi}$. This is similar to levels seen today in countries regarded as demonstrating best practice in this area: In 2014, an average Dutch person cycled almost $1000 \mathrm{~km}$ per year, corresponding to around $9 \%$ of total distance travelled and a trip mode share of $28 \%$ 

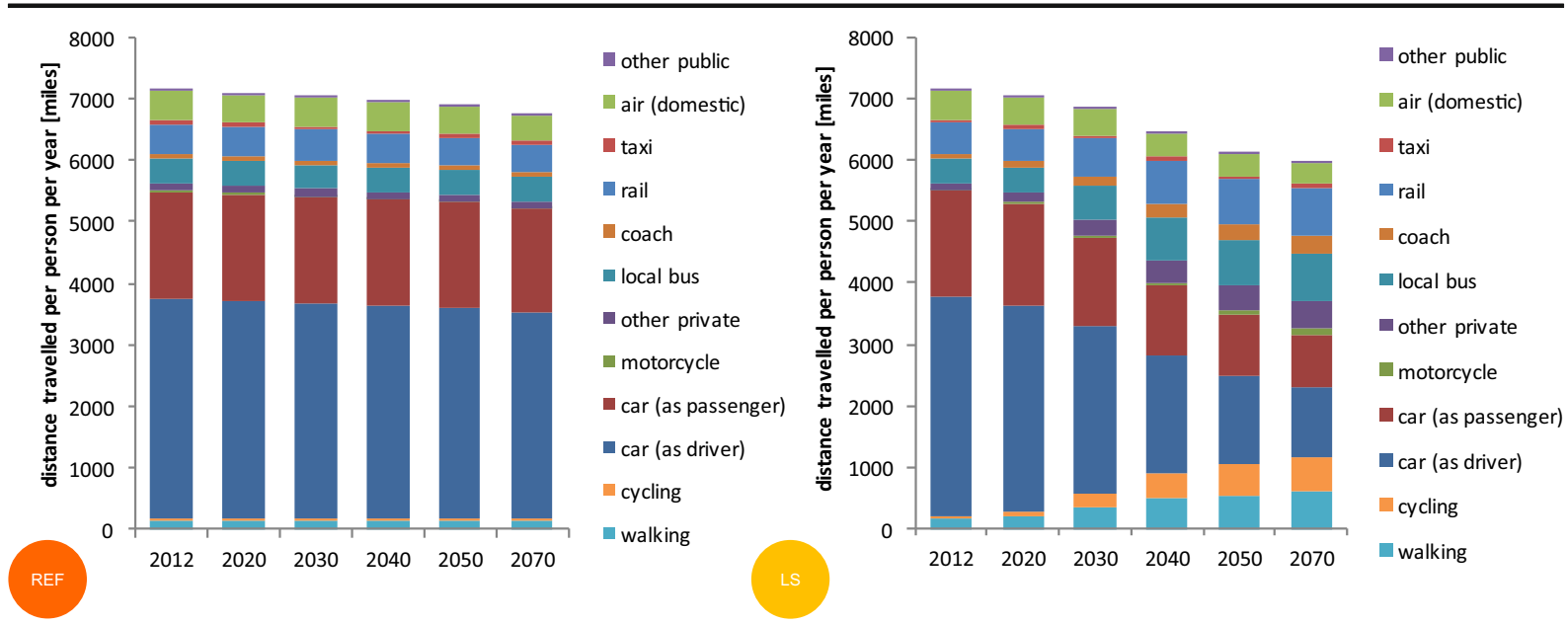

Fig. 2 Average distance travelled per person per year by transport mode, REF and EV scenarios on the left, LS and LS EV scenarios on the right

(Statistics Netherlands 2016). It also sits well with Transport Scotland's target of ' $10 \%$ of everyday journeys to be made by bike, by 2020' (Transport Scotland 2017). It may have been possible to have employed even greater ambition here given that the Dutch have achieved this level of cycling already without comprehensive banning of conventionally fuelled vehicles from urban centres proposed in this scenario. If cycling and walking are added together, 'slow modes' account for $17 \%$ of distance in 2050 .

\section{Air travel}

Domestic flights are assumed to saturate and decrease due to increasing use of much improved intercity rail and express coaches and a frequent flyer levy (Devlin and Bernick 2015). Flying becomes a luxury and increasingly uncompetitive on the basis of time and cost for most domestic routes as the price increases and rail and coach travel (taking on road capacity left by less car travel) are improved. Domestic air-miles in the lifestyle (LS, LS EV) variants are thus 4 and $21 \%$ lower in 2030 and 2050, respectively, than in the REF and EV cases. Frequent international air travel is also increasingly becoming unacceptable so that air-miles in the lifestyle variants are 4 and $15 \%$ lower in 2030 and 2050, respectively.

\section{Freight transport}

Driven by the move towards a service economy and increased use of 'smart' home delivery of groceries and other goods, light commercial vehicle (LCV, i.e. vans) traffic in a Lifestyle world continues to increase as it did in the decade prior to 2012 , growing by $54 \%$ by 2050 over the 2012 levels. However, as LCV technology and urban delivery logistics improve, their use is optimised and average distances travelled per van decrease somewhat. Local traffic regulations will give priority to professional home delivery and consolidated urban distribution with clean vehicles. Town/city centres increasingly ban heavy goods vehicles (HGV) but allow electric delivery vans. As a result, the overall distance travelled by vans will decrease by $24 \%$ by 2050 in the LS and LS EV scenarios when compared to the REF and EV scenarios. HGVs are still set to grow (by $8 \%$ between 2012 and 2050) due to economic and population growth, but overall distance travelled by these vehicles in the LS and LS EV scenarios will fall by 11 (2030) and 24\% (2050) when compared to the REF and EV scenarios, mainly as a result of increased load factors through business-led vehicle utilisation measures and consolidation centres (Hickman and Banister 2007; Sims et al. 2014). Rail and waterborne freight play a bigger role, mainly due to mode shift from roads. These changes implied that the road freight elasticity of demand with respect to GDP decreased from 0.8 in 2012 (i.e. within the range reported in Dunkerley et al. (2014)) to -0.6 in 2050 in REF, whereas it decreased further to -0.3 in the Lifestyle scenarios.

\section{Driving style and on-road fuel efficiency}

Efficiency, quality and reliability overtake speed as the priority for travel in the Lifestyle scenarios. This is brought 
Fig. 3 Scenario comparison of new car sales in 2012, 2020, 2030 and 2050. ICV internal combustion vehicle, HEV hybrid electric vehicle, PHEV plug-in hybrid electric vehicle. This shows only gasoline, diesel and electricity-based propulsions systems, as none of the alternative propulsion systems (B100 ICV, E85 ICV, LPG ICV, CNG ICV, hydrogen FCEV) were taken up significantly enough to show on the graph

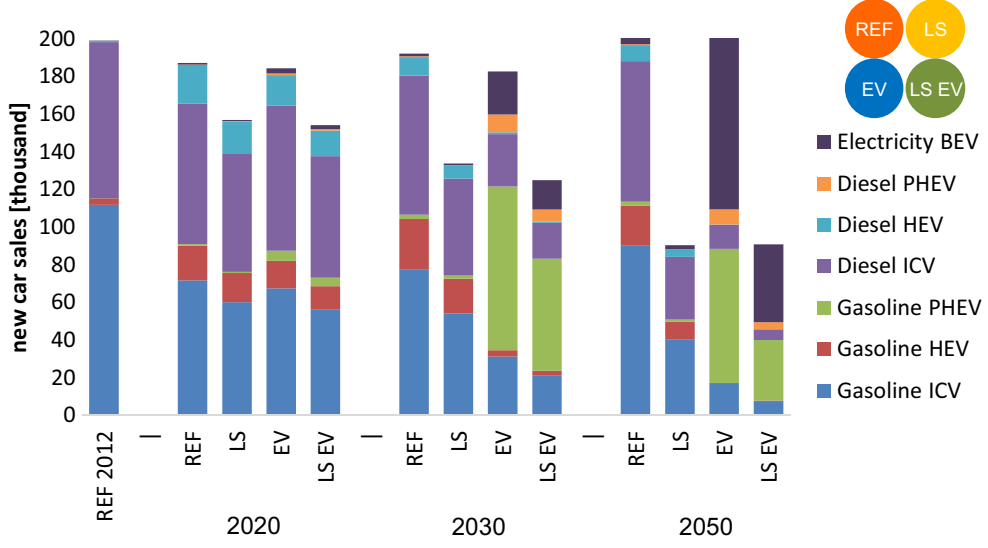

about by higher costs of motoring and the social pressure to improve driving standards for both safety and environmental reasons. Breaking the speed limit (presently about half of all motorway driving) becomes socially unacceptable as it is seen as wasteful. Elements of partial vehicle automation ensure speed limit compliance and also steady driving (Wadud et al. 2016). We assumed that new drivers will start to practice eco-driving techniques, and for others, the effectiveness will begin to 'trail off', although it is assumed that the behaviour is reinforced by (a) repeat training programmes and campaigns (so that it becomes more or less habitual) and (b) through increased automation and information feedback in vehicles. Even for those who are practicing it, not every mile they drive will be affected. For cars, this increases from $3.6 \%$ in 2012 to $41 \%$ in 2025 , then levelling off at $62 \%$ from 2035 . For those miles affected, an $8 \%$ efficiency improvement is assumed, which is at the lower end of the evidence base (Alam and McNabola 2014; Gross et al. 2009; Ho et al. 2015; Luijt et al. 2017). Business uptake of eco-driving is expected to be quicker as it is easier to integrate training programmes and instrumentation. Eco-driving will also be practiced by van and HGV drivers. Diffusion through the van fleet is expected to mirror that of car business travel, and penetration through the truck fleet is the same as for vans. However, the savings per mile are lower (4\%), as these vehicles are already speed limited.

\section{Vehicle technology choice and use}

In the EV and LS EV scenarios, private, fleet and commercial buyers increasingly prefer electric vehicles over conventional internal combustion vehicles, fuelled by a co-evolving EV market with increasing availability and performance of lower carbon vehicles, investment in home and fast recharging infrastructure, and supporting low carbon pricing policy for ULEVs. Petrol and diesel ICVs (and later HEVs) are gradually phased out of the market as cities start banning conventional ${ }^{8}$ vehicles (in line with the ban on sales of new conventional petrol and diesel cars and vans by 2040, HM Government 2017) and favouring EVs through parking and access incentives.

As a result, in both 'EV' and 'LS EV', conventional vehicles continue to be the main focus in the short-term before ULEV (essentially PHEV and BEV) reach approximately $10 \%$ of market share in the early 2020 s, driven by the fleet and early adopter markets. Take-up by the mass market and so-called 'user-choosers' (Brand et al. 2017) in the late 2020s mean that PHEV car sales reach the $50 \%$ mark by 2032 before increasingly better performing BEVs take over as the dominant choice of vehicle from about 2040, especially for cars and vans in urban areas. As illustrated for cars in Fig. 3, while in 2016, only about $2 \%$ of new cars were plug-in vehicles, the EV and LS EV scenarios suggest that by $2030,63 \%$ of new cars could be plug-in vehicles. By 2050, $85 \%$ of new cars could be plug-in. HEV sales remain significant only in the REF (and to some extent the LS) scenario due to their fuel economy and benefits (while being slightly more expensive than the ICV equivalent). Note that the lifestyle scenarios result in much lower overall car ownership (and therefore sales) levels in the second half of the assessment period, reflecting the tendency towards less overall car use, more use of MaaS and the increased membership of

\footnotetext{
$\overline{8}$ 'Conventional' was considered to include incumbent ICV and HEV but not plug-in vehicles. This differs from the current, less ambitious UK Government strategy that excludes new HEV from the ban.
} 
car clubs for use of a variety of types of cars for longer distance journeys.

The changes in overall traffic levels, modal shares and the increased demand for lower carbon vehicles are further illustrated in Figs. 4 (passenger) and 5 (freight), showing road vehicle traffic on Scottish roads (in billion vehicle-km) in the 'REF' (on the left) and LS EV (on the right) scenarios. In LS EV, passenger road vehicle-km decreased considerably (while they increased slightly in REF), and conventional ICV and HEV technology is gradually replaced by PHEV and, later, BEV traffic (Fig. 4). While by 2020 , only $1 \%$ of car traffic was by plug-in vehicles, and this share increased rapidly to $8 \%$ in $2025,29 \%$ in 2030 and further to a dominating $84 \%$ by 2050. Hybrid EV technology peaked at $9.2 \%$ of all car traffic in 2025. Similarly, traffic by HEV buses in LS EV did not go much beyond $2 \%$ of all bus traffic, and zero emission BEV buses made up 3\% of bus traffic in 2020, rising to $21 \%$ in 2030 and $55 \%$ in 2050 . The rise of motorcycle traffic reflects the mode shift from car trips.

Overall, road freight increases considerably, even in LS EV (Fig. 5). Advanced ICV, PHEV and, slightly later, BEV technologies dominate urban van traffic over the assessment period. Medium and heavy trucks continue to be ICV based, with some penetration of $\mathrm{HEV}$ and BEV technology in the later stages.

\section{Impact on transport energy use}

Final energy demand is nearly halved in the transport sector by 2050 in the combined LS EV scenario compared to the reference case (REF) (Fig. 6). Lifestyle change on its own (i.e. the LS scenario) was much less effective, reducing transport energy demand by only $14 \%$ by 2030 and by $31 \%$ by 2050 compared to the reference case (REF). Nevertheless, reductions were even lower in the EV technology scenario $(\mathrm{EV})$ at 8 (2030) and 25\% (2050) due to travel demand increasing. When compared to baseline (REF), the demand for conventional fuels (petrol, diesel) was 35\% lower in 2050 in the LS scenario and less than half in the combined lifestyle and EV technology case (LS EV). By comparison, electricity demand grew steeply in both EV scenarios, rising from its 2012 base of just $1.3 \%$ (largely rail) to around $20 \%$ of total fuel demand by 2050 in both the EV and LS EV scenarios (Fig. 6). Note, however, that total electricity demand was lower in the LS EV scenario than the EV scenario, as overall demand was lower due to lifestyle change.
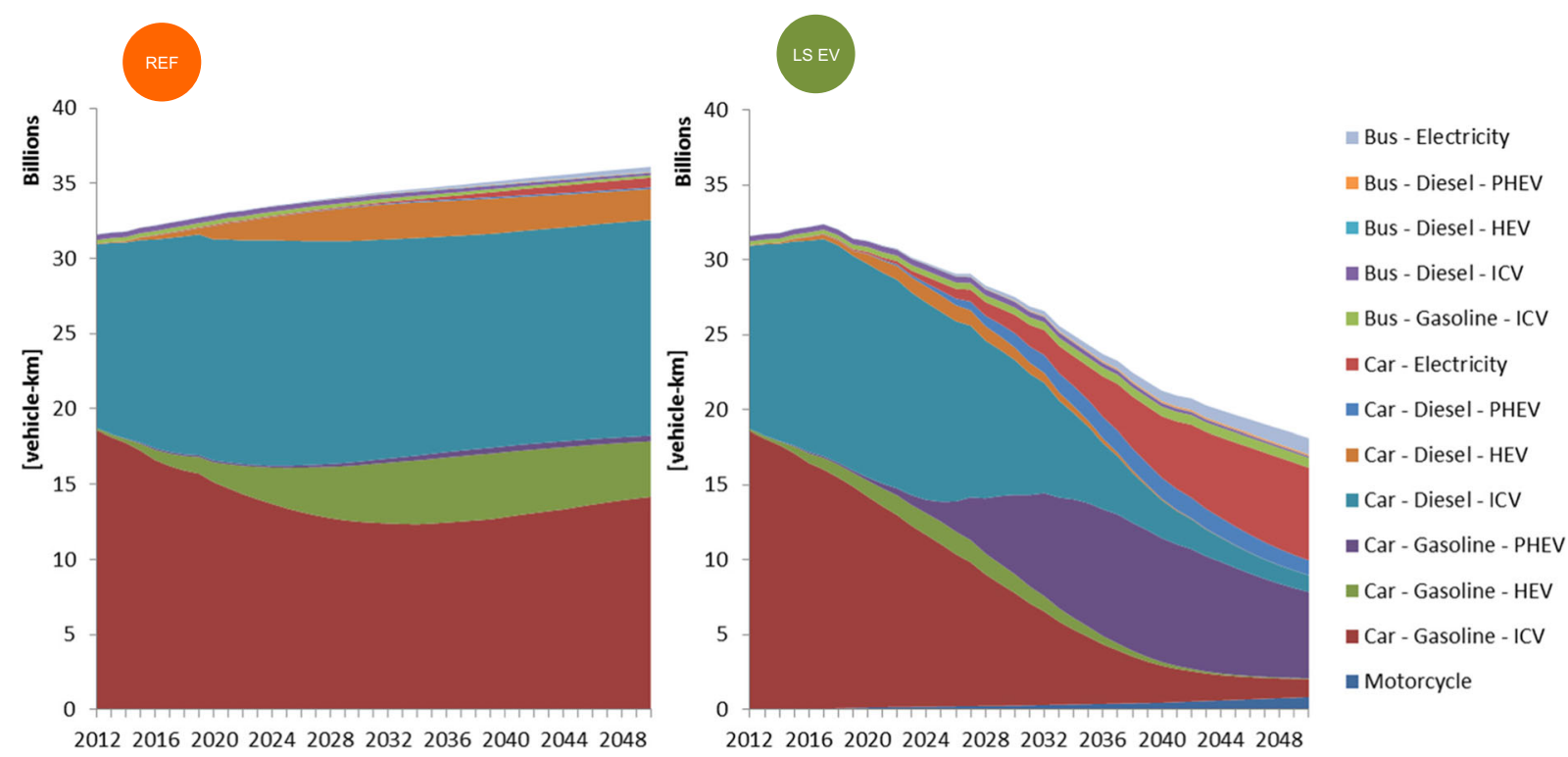

Note: This shows only gasoline, diesel and electricity based propulsions systems, as none of the alternative propulsion systems (B100 ICV, E85 ICV, LPG ICV, CNG ICV, hydrogen FCEV) were taken up significantly enough to show on the graph.

Fig. 4 Scenario comparison of road passenger traffic by propulsion system, 'REF' vs. 'LS EV'. This shows only gasoline, diesel and electricity-based propulsions systems, as none of the alternative propulsion systems (B100 ICV, E85 ICV, LPG ICV, CNG ICV, hydrogen FCEV) were taken up significantly enough to show on the graph 

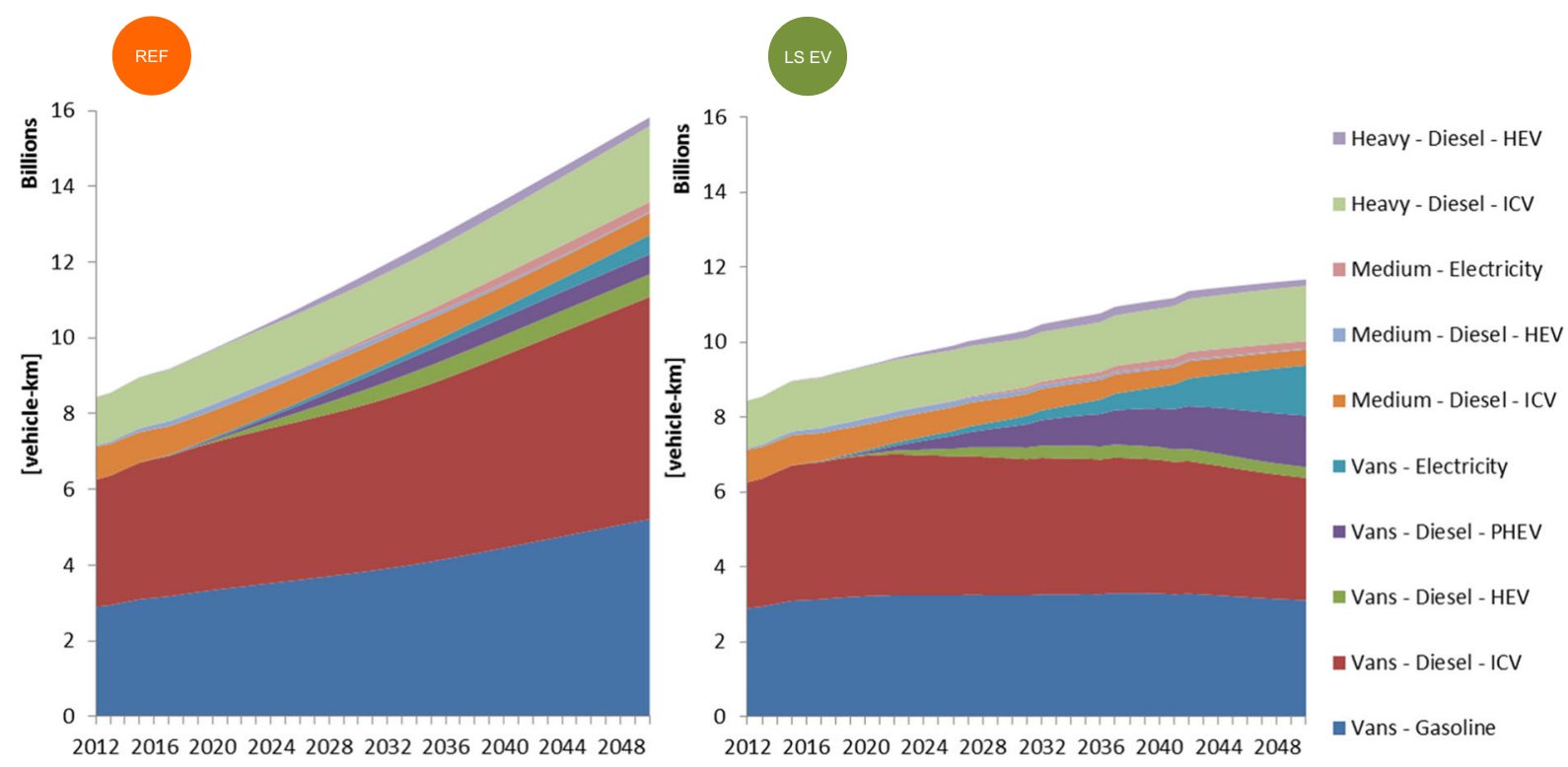

Note: This shows only gasoline, diesel and electricity based propulsions systems, as none of the alternative propulsion systems (B100 ICV, E85 ICV, LPG ICV, CNG ICV, hydrogen FCEV) were taken up significantly enough to show on the graph.

Fig. 5 Scenario comparison of road freight traffic by propulsion system, 'REF' vs. 'LS EV'. This shows only gasoline, diesel and electricity-based propulsions systems, as none of the alternative

\section{Impact on transport carbon emissions}

The lifestyle (LS) scenario resulted in 12 and $28 \%$ reductions in direct transport $\mathrm{CO}_{2}$ emissions (i.e. at source) by 2030 and 2050 compared to baseline (REF) levels (Fig. 7), with reductions over 2012 of 25 (2030) and $46 \%$ (2050). This was largely due to reductions from car emissions, but somewhat offset by increases in bus, propulsion systems (B100 ICV, E85 ICV, LPG ICV, CNG ICV, hydrogen FCEV) were taken up significantly enough to show on the graph

rail and motorcycle emissions due to mode shift. The techno-centric EV scenario reached similar reductions only in the second half of the assessment period, largely due to higher plug-in vehicle shares and zero emissions at point of use. $\mathrm{CO}_{2}$ emission reductions were greatest in the combined LS EV scenario, with emissions in 2050 less than half the level of 2012 and $43 \%$ lower than baseline (REF). Thus, lifestyle change makes the achievement of
Fig. 6 Transport energy demand (in PJ) for the main transport fuels - scenario comparison

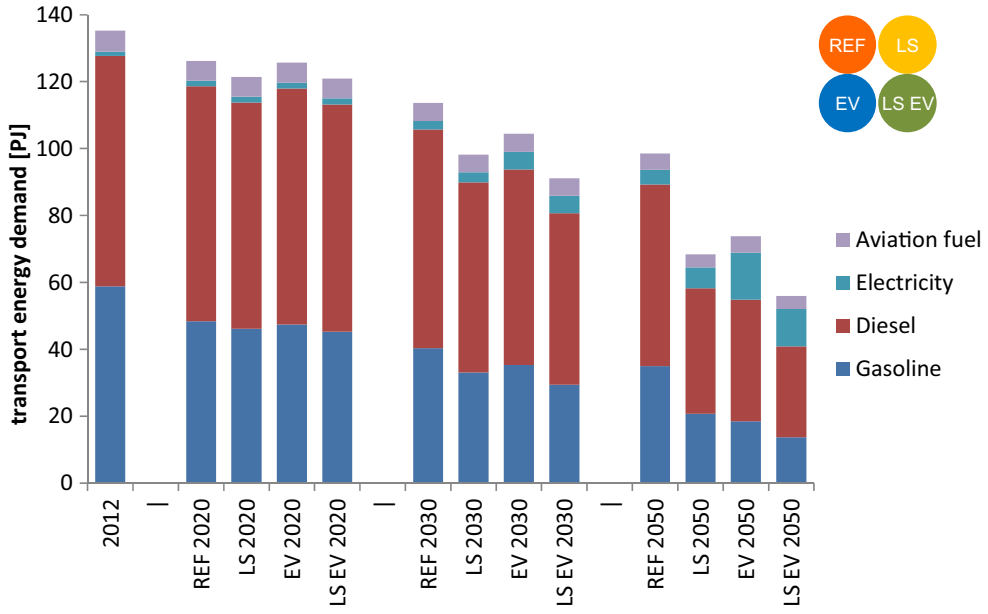


Fig. 7 Projections of $\mathrm{CO}_{2}$ emissions (in Mt) at source from transport in each scenario

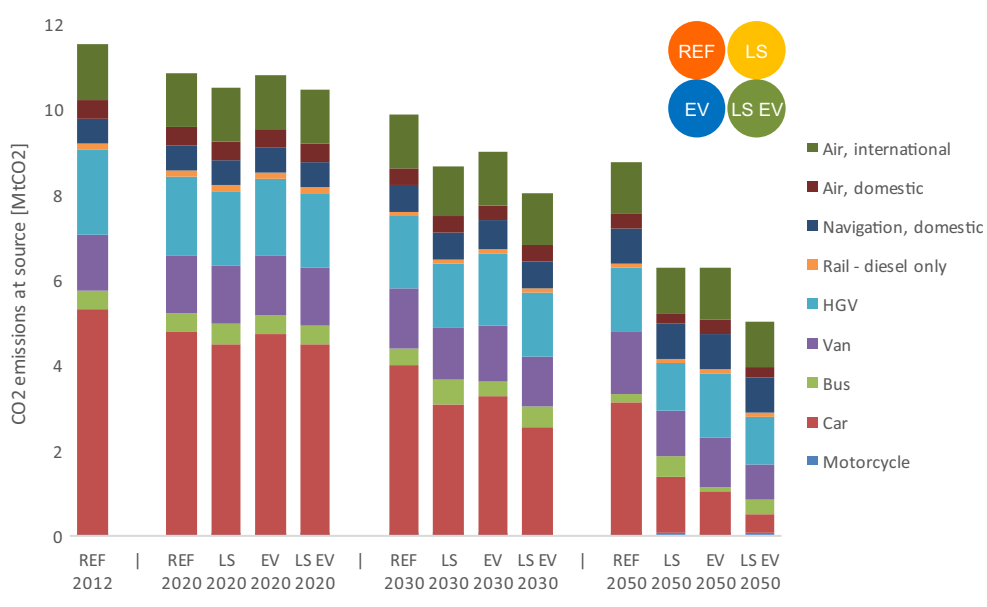

deep decarbonisation somewhat easier, with fewer changes required to the transport-energy system.

We further assessed life cycle $\mathrm{CO}_{2}$ equivalent $\left(\mathrm{CO}_{2} \mathrm{e}\right)$ emissions based on the 100-year Global Warming Potential (Allen et al. 2016; Borken-Kleefeld et al. 2013), which include upstream emissions from power generation and fuel production, as well as vehicle manufacture, maintenance and disposal. For the LS scenario, life cycle carbon emissions were 14 (2030) and 31\% (2050) lower than baseline. This could not be matched by the technology-led EV scenario, with reductions of 7 (2030) and 22\% (2050) compared to baseline.

Finally, when looking at cumulative emissions, the combined LS EV scenario unsurprisingly saved the largest amount between 2012 and 2050 (nearly 100 $\mathrm{MtCO}_{2} \mathrm{e}$, see also Table 2), followed by the lifestyle change (72 $\left.\mathrm{MtCO}_{2} \mathrm{e}\right)$ and EV technology pathway (41 $\left.\mathrm{MtCO}_{2} \mathrm{e}\right)$ scenarios. This is due to the lifestyle change scenario reducing demand and therefore emissions earlier as well as the implicit lower indirect emissions from fuel and vehicle production and disposal.

\section{Impact on transport air quality emissions}

Strategies designed to promote ULEVs and 'discourage' petrol and diesel sales for road transport in Scotland can have significant impacts on air quality emissions. While all scenarios exhibit a similar downward trend in the short-term, from the mid2020s onwards, direct $\mathrm{NO}_{\mathrm{X}}$ emissions from all surface transport (road, rail) decreased more in the EV scenario $(-9 \%$ by $2030,-34 \%$ by 2050 when compared to REF) than in the lifestyle scenario $(-4 \%$ by
$2030,-20 \%$ by 2050 when compared to REF) (Fig. 8). Direct $\mathrm{PM}_{2.5}$ emissions from surface transport decreased more in the first half of the period for the technology-led EV scenario ( $-5 \%$ by 2030 ) than in the lifestyle scenario ( $-2 \%$ by 2030 ) before showing similar reductions in the second half $(-15 \%$ by 2050 for both scenarios). This suggests that in order to reduce the health burden of road and rail traffic pollution, the transformation to a cleaner ULEV vehicle fleet may be more effective than demand reductions and radical mode shift.

\section{Discussion}

\section{Key findings}

This study found that the carbon budgets set by subnational policy in Scotland may only be achieved in a radical lifestyle and high EV pathway future (LS EV), as summarised in Table 2. While the results are plausible, they will be very difficult to achieve without early action and a holistic, integrated approach as depicted in the LS EV scenario. Even then, the results suggest that the $1.5 \mathrm{C}$ target (that goes beyond the legally binding $80 \%$ target set for the whole economy) will be very tough to meet in Scotland without further action on heavy goods vehicles, international aviation and shipping (where electrification is problematic), and further decarbonisation of the power sector beyond 2030 .

The most significant impact of lifestyle change on the transport-energy system is due to reductions in 

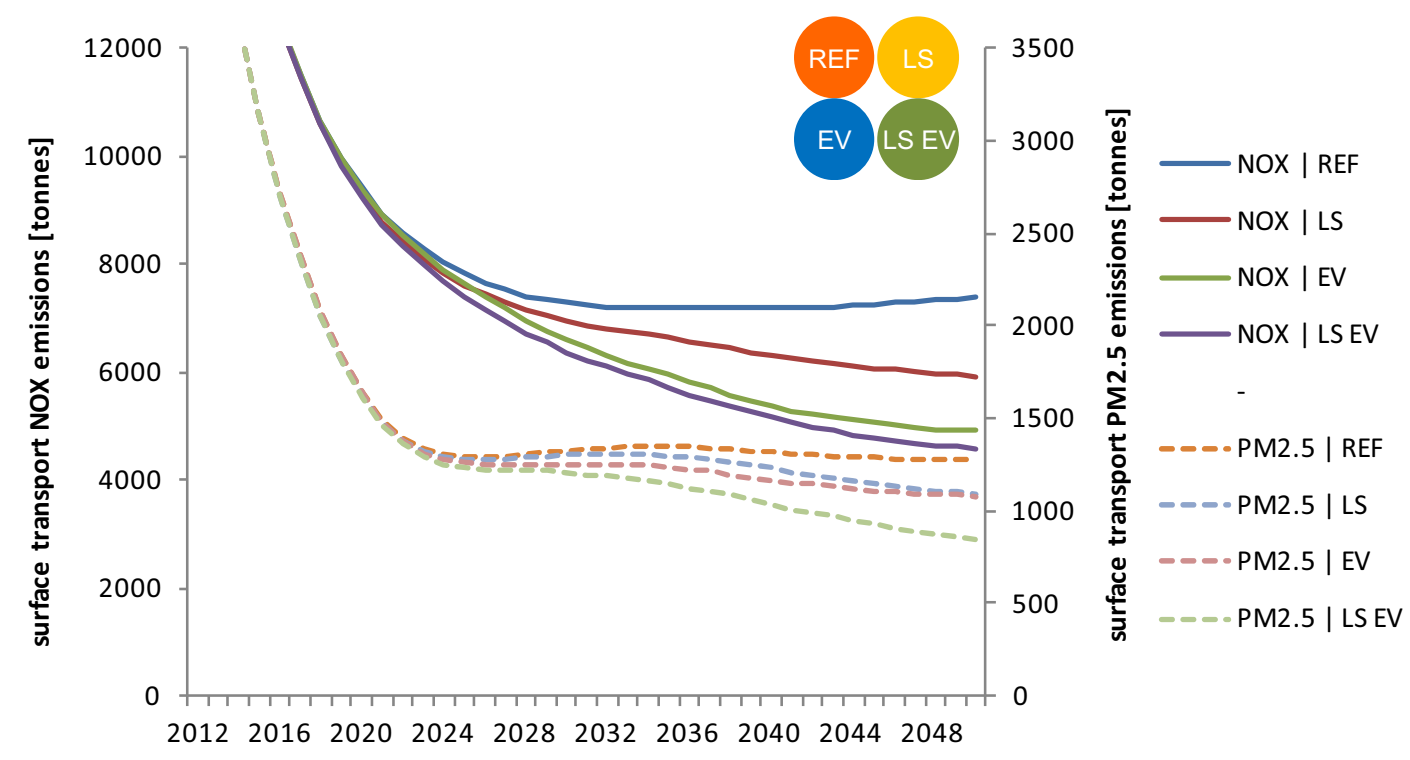

Fig. 8 Projections of $\mathrm{NO}_{\mathrm{X}}$ and $\mathrm{PM}_{2.5}$ emissions at source from surface transport in each scenario

the overall demand for transport energy, particularly for fossil fuels. Lower transport energy demands bring benefits for energy system costs, carbon emissions and energy import requirements. Lifestyle change alone (without an EV transition) has a similar effect on total transport energy demand to a transition to EVs with no lifestyle change. This has important implications for climate mitigation policy. A scenario that involves lifestyle change will place much less pressure on policy to require rapid (and potentially disruptive) technical change, including technologies at the point of use. This holds true even if the power sector were to decarbonise further than what has been assumed in this study beyond 2030 .

Of course, the big question is, can it be achieved on this scale and timescale? Travel demand management strategies in Scotland (such as the Smarter Choices Smarter Places programme), while having a number of local successes, have failed to deliver widespread changes in mobility practices to date (Scottish Government 2013a). Yet, when looking into the medium to long-term future, we have assumed nothing extraordinary by looking at best practice in OECD countries (e.g. 'going Dutch' on active travel in urban areas for certain trip purposes) on trip lengths and trip rates by trip purpose, mode shift and occupancy rates, and ULEV uptake and use. By encouraging lifestyle change, policy is assumed to co-evolve with and support the main drivers behind lifestyle change, that is, changes in social norms and attitudes towards travel, cultural shifts away from motorisation/mobility to accessibility and an increased emphasis on resilience/less disruption. In turn, the changing attitudes and norms allow more radical policies to be implemented: for example, a ban on binge flying (Cohen et al. 2011), a 'frequent flyer levy' (Devlin and Bernick 2015) and radical car restraint policies in urban areas (Banister and Hickman 2013; ECMT 2006). The supporting policy environment is based around soft measures, e.g. smarter choices, smarter places, large scale and sustained awareness campaigns (so that people attribute their own behaviour and transport choices to, say, climate disasters and high air pollution episodes), pricing incentives that favour localised trips and shorter distances, zone/access restrictions, regulation to 'lock in' market transformation, and so on. The same question might also be asked of the rate of progress on technical change. How achievable are, say, significant cost reductions for ULEVs and widespread (not just Scotland) investments in charging infrastructures at home and a reconfiguration of the existing petrol station network? The latter may include non-trivial investment in the local electricity grid infrastructure. Given the scarcity of public funds to fuel the technology (r)evolution, who will be delivering and governing this transition? Hence, the assumption that encouraging lifestyle change and 
reductions in demand present more problematic issues for policy makers than techno-centric solutions may not necessarily be correct (Creutzig et al. 2018).

\section{Strength and limitations}

The integrated modelling approach allowed us to place the potential phasing out of petrol and diesel vehicles and electrification of the car market in the context of radical changes in travel behaviours on the basis of their transport, energy and lifecycle emissions impacts. It may therefore have a broader remit and wider range of applications in scenario and policy studies than, for instance, the top-down 'ASIF' (Schipper 2011) decomposition framework, sectoral models that lack endogenising consumer behaviour (Fontes and Pereira 2014; Rogan et al. 2011), or integrated assessment models that by and large favour technology solutions and fuel shifts over travel activity and consumer behaviour modelling (Creutzig 2015; McCollum et al. 2012; Oxley et al. 2013).

However, there are some notable limitations of this study. The scenario modelling approach used here is suited to long-term studies of more radical socio-technical developments. As such, it is simulating the future rather than predicting it. However, the forecasting and prediction of the medium to longterm future beyond, say, 2025 based on historic values, habits and norms may be inappropriate and misleading if taken as 'truth' (for instance by policy makers). We believe that the more flexible scenario approach adopted here of developing structured and plausible 'storylines' and breaking down travel choices into their constituent journey purposes, lengths and modes together with a sophisticated and policy-relevant supply model may be well suited to initiate debate on social transitions and the transport and energy policies to support them.

The focus on the subnational level of Scotland (5.4 million inhabitants) may have limitations in terms of depicting longer-term changes of say travel activity and vehicle ownership that will manifest differently according to social and geographical context. We are therefore developing a geographically (or rather, administratively) disaggregate version of STEAM that models all 32 Local Authority areas in the country. While allowing for a more refined assessment of geographical differences, data availability becomes problematic and cross-border movements an even more complex issue. Obviously, there are many assumptions behind the quantification of the storylines, clearly too many to provide in the space of a journal paper. We have provided the key assumptions and data and are happy to provide further details on request. Further work may explore zero carbon and zero air quality emissions strategies that may go beyond the radical changes explored in this study.

\section{Conclusion}

By going beyond a more traditional techno-centric approach to carbon and air quality emission mitigation, this paper presents results of a socio-technical modelling approach which characterised patterns of travel behaviour consistent with a more sustainable society and then 'pitched' these against a technology, policy and consumer-led high EV pathway. This necessarily involves 'what if' scenario planning, which is not intended to allow the emergence of a single vision for the future but rather to challenge policymakers to consider how to formulate both 'soft' and 'hard' policies that realise the change which is required so that the ambitious climate change and air quality objectives are met.

Given the many uncertainties involved in decarbonising the transport sector, there are strong arguments for pursuing both demand and supply side solutions in order to make the path to deep decarbonisation more sustainable and potentially more certain. Scottish climate change policy gives more attention to demand-side measures to reduce total kilometres travelled or shift to less carbon intensive modes of transport than the UK or other countries. This paper goes some way to take this further, and faster. The newfound urgency of 'cleaning up our act' since the Paris Agreement and Dieselgate scandal suggests that we cannot just wait for the 'technology fix'.

Acknowledgments The research supporting this paper was undertaken for the UK Energy Research Centre. CB and JA received funding by the UK Research Councils (award EP/L024756/1), and $\mathrm{CM}$ by the ClimateXChange centre of expertise in Scotland.

\section{Compliance with ethical standards}

Conflict of interest The authors declare that they have no conflict of interest. 


\section{Appendix}

Table 3 Passenger travel demand indicators, lifestyle scenarios (LS and LS EV)

\begin{tabular}{|c|c|c|c|c|c|c|}
\hline & 2012 & 2020 & 2030 & 2040 & 2050 & Comment/source \\
\hline \multicolumn{7}{|l|}{ Number of trips } \\
\hline $\begin{array}{l}\text { Commuting, reduction due } \\
\text { to teleworking }\end{array}$ & $3 \%$ & $4 \%$ & $5 \%$ & $10 \%$ & $15 \%$ & $\begin{array}{l}\text { The uptake in teleworking is reinforced by tax incentives, } \\
\text { travel plans, broadband-roll-out and road user charges } \\
\text { and parking charges }\end{array}$ \\
\hline $\begin{array}{l}\text { Business travel, reduction } \\
\text { due to tele/video conferencing }\end{array}$ & $5 \%$ & $6 \%$ & $8 \%$ & $17 \%$ & $25 \%$ & $\begin{array}{l}\text { Going Smarter report (Scottish Government } 2013 \text { ) } \\
\text { concludes that tele/video conferencing could reduce } \\
\text { business trips by } 18 \% \text { after } 10 \text { years. Extrapolate this } \\
\text { on to reach } 25 \% \text { maximum reduction in trips by } 2050 \\
\text { on the basis that there are many business trips e.g. } \\
\text { nursing which cannot and simply will not be avoided. } \\
\text { TC share in } 2012 \text { is assumed to be } 5 \% \text {. These } \\
\text { proportional reductions will also apply to air trips }\end{array}$ \\
\hline $\begin{array}{l}\text { Local leisure, increase due to } \\
\text { shift to more local trips }\end{array}$ & $0 \%$ & $1 \%$ & $3 \%$ & $7 \%$ & $10 \%$ & $\begin{array}{l}\text { There is a general shift in all age groups towards more } \\
\text { local leisure trips for at the expense of longer trips, } \\
\text { so a small increase is assumed due to this effect }\end{array}$ \\
\hline $\begin{array}{l}\text { Long distance leisure in } \\
\text { Scotland, increase due to } \\
\text { holidaying at home }\end{array}$ & $0 \%$ & $0 \%$ & $0 \%$ & $0 \%$ & $0 \%$ & $\begin{array}{l}\text { Fewer people travelling abroad means more domestic } \\
\text { holidays - however, the increase in weekends away } \\
\text { will be neutralised by fewer distance day trips (due to } \\
\text { affordability as price of travel increases) with people } \\
\text { using their local area more instead }\end{array}$ \\
\hline $\begin{array}{l}\text { Shopping, increase due to more } \\
\text { walking and cycling }\end{array}$ & $0 \%$ & $2 \%$ & $5 \%$ & $8 \%$ & $10 \%$ & $\begin{array}{l}\text { Based on figures in Going Smarter report (Scottish } \\
\text { Government 2013a) }\end{array}$ \\
\hline $\begin{array}{l}\text { Shopping, reduction due } \\
\text { to teleshopping }\end{array}$ & $0 \%$ & $1 \%$ & $3 \%$ & $7 \%$ & $10 \%$ & $\begin{array}{l}\text { Going Smarter report (Scottish Government 2013a) } \\
\text { suggests that home shopping could reduce vehicle } \\
\text { mileage for shopping by } 4 \% \text { after } 10 \text { years. Here, } \\
\text { we assume 3\% trips by } 2030 \text { and } 10 \% \text { by } 2050 \text {. } \\
\text { (However, there will be an effect on van use.) }\end{array}$ \\
\hline $\begin{array}{l}\text { Other trips, decrease due } \\
\text { to tele-activity }\end{array}$ & $0 \%$ & $1 \%$ & $3 \%$ & $8 \%$ & $12 \%$ & $\begin{array}{l}\text { It will increasingly be the norm to access many services } \\
\text { such as banking and medical care on-line }\end{array}$ \\
\hline \multicolumn{7}{|l|}{ Trip length } \\
\hline $\begin{array}{l}\text { Commuting, reduction due } \\
\text { to more teleworking }\end{array}$ & $0 \%$ & $1 \%$ & $2 \%$ & $4 \%$ & $6 \%$ & $\begin{array}{l}\text { Teleworking abstracts the longer commute trips and } \\
\text { therefore has a disproportionately large impact on } \\
\text { average trips lengths }\end{array}$ \\
\hline $\begin{array}{l}\text { Commuting, reduction due } \\
\text { to proximity principle }\end{array}$ & $0 \%$ & $1 \%$ & $3 \%$ & $9 \%$ & $15 \%$ & $\begin{array}{l}\text { The proximity principle assumes that there is a movement } \\
\text { towards living closer work places }\end{array}$ \\
\hline $\begin{array}{l}\text { Business travel, reduction } \\
\text { due to more tele/video } \\
\text { conferencing }\end{array}$ & $0 \%$ & $1 \%$ & $3 \%$ & $9 \%$ & $15 \%$ & $\begin{array}{l}\text { Assumed that the longest trips are increasingly } \\
\text { substituted by tele-video conferencing }\end{array}$ \\
\hline $\begin{array}{l}\text { Long distance leisure, } \\
\text { more weekends away }\end{array}$ & $0 \%$ & $0 \%$ & $0 \%$ & $0 \%$ & $0 \%$ & $\begin{array}{l}\text { There are fewer day trips and more people cycling and } \\
\text { walking from home but some longer holiday trips } \\
\text { (weekends away) to replace travel abroad-means that } \\
\text { on balance average distance stays the same }\end{array}$ \\
\hline $\begin{array}{l}\text { Local leisure, switch to } \\
\text { local W\&C trips }\end{array}$ & $0 \%$ & $0 \%$ & $0 \%$ & $0 \%$ & $0 \%$ & $\begin{array}{l}\text { Although there is a shift towards walking and cycling } \\
\text { around the local area, this does not reduce the average } \\
\text { length of local leisure trips. With leisure, it is mainly } \\
\text { modes that change, not the number or length of trips }\end{array}$ \\
\hline $\begin{array}{l}\text { School, reduction due to } \\
\text { proximity principle }\end{array}$ & $0 \%$ & $1 \%$ & $3 \%$ & $9 \%$ & $15 \%$ & $\begin{array}{l}\text { School selection policy is revised to insist that 'local } \\
\text { schools' are chosen }\end{array}$ \\
\hline $\begin{array}{l}\text { Shopping, reduction due to } \\
\text { more local shopping }\end{array}$ & $0 \%$ & $2 \%$ & $5 \%$ & $10 \%$ & $15 \%$ & $\begin{array}{l}\text { Restriction of cars in urban areas means that shorter, } \\
\text { local journeys become more attractive }\end{array}$ \\
\hline $\begin{array}{l}\text { Other trips, reduction due } \\
\text { to proximity principle }\end{array}$ & $0 \%$ & $1 \%$ & $3 \%$ & $9 \%$ & $15 \%$ & $\begin{array}{l}\text { Re-introduction of local clinics, post office/banking } \\
\text { services, etc. especially in rural areas. Restriction } \\
\text { of cars in urban areas means that shorter, local journeys } \\
\text { become more attractive }\end{array}$ \\
\hline
\end{tabular}


Table 4 Mode shift by trip length, lifestyle scenarios (LS and LS EV)

\begin{tabular}{|c|c|c|c|c|}
\hline Trip length & Mode shift & 2020 & 2030 & 2050 \\
\hline \multirow[t]{8}{*}{$0-1 \mathrm{mi}$} & From car/van driver to walk & $2 \%$ & $8 \%$ & $20 \%$ \\
\hline & From car/van driver to bicycle & $1 \%$ & $5 \%$ & $13 \%$ \\
\hline & From car/van driver to local bus & $1 \%$ & $3 \%$ & $8 \%$ \\
\hline & From car/van passenger to walk & $2 \%$ & $8 \%$ & $20 \%$ \\
\hline & From car/van passenger to bicycle & $1 \%$ & $3 \%$ & $8 \%$ \\
\hline & From car/van passenger to local bus & $1 \%$ & $3 \%$ & $8 \%$ \\
\hline & From local bus to walk & $1 \%$ & $5 \%$ & $13 \%$ \\
\hline & From local bus to bicycle & $1 \%$ & $3 \%$ & $8 \%$ \\
\hline \multirow[t]{10}{*}{$1-2 \mathrm{mi}$} & From car/van driver to walk & $3 \%$ & $10 \%$ & $25 \%$ \\
\hline & From car/van driver to bicycle & $1 \%$ & $5 \%$ & $13 \%$ \\
\hline & From car/van driver to motorcycle & $0 \%$ & $1 \%$ & $2 \%$ \\
\hline & From car/van driver to local bus & $1 \%$ & $3 \%$ & $8 \%$ \\
\hline & From car/van passenger to walk & $3 \%$ & $10 \%$ & $25 \%$ \\
\hline & From car/van passenger to bicycle & $1 \%$ & $5 \%$ & $13 \%$ \\
\hline & From car/van passenger to motorcycle & $0 \%$ & $1 \%$ & $2 \%$ \\
\hline & From car/van passenger to local bus & $1 \%$ & $3 \%$ & $8 \%$ \\
\hline & From local bus to walk & $1 \%$ & $5 \%$ & $13 \%$ \\
\hline & From local bus to bicycle & $1 \%$ & $3 \%$ & $8 \%$ \\
\hline \multirow[t]{10}{*}{$2-5 \mathrm{mi}$} & From car/van driver to walk & $1 \%$ & $5 \%$ & $13 \%$ \\
\hline & From car/van driver to bicycle & $1 \%$ & $5 \%$ & $13 \%$ \\
\hline & From car/van driver to motorcycle & $0 \%$ & $1 \%$ & $2 \%$ \\
\hline & From car/van driver to local bus & $1 \%$ & $5 \%$ & $13 \%$ \\
\hline & From car/van passenger to walk & $1 \%$ & $4 \%$ & $10 \%$ \\
\hline & From car/van passenger to bicycle & $1 \%$ & $4 \%$ & $10 \%$ \\
\hline & From car/van passenger to motorcycle & $0 \%$ & $1 \%$ & $2 \%$ \\
\hline & From car/van passenger to local bus & $1 \%$ & $5 \%$ & $13 \%$ \\
\hline & From local bus to bicycle & $1 \%$ & $5 \%$ & $13 \%$ \\
\hline & From rail/underground to bicycle & $1 \%$ & $5 \%$ & $13 \%$ \\
\hline \multirow[t]{10}{*}{$5-10 \mathrm{mi}$} & From car/van driver to bicycle & $1 \%$ & $3 \%$ & $8 \%$ \\
\hline & From car/van driver to motorcycle & $0 \%$ & $1 \%$ & $2 \%$ \\
\hline & From car/van driver to local bus & $2 \%$ & $8 \%$ & $20 \%$ \\
\hline & From car/van driver to rail/underground & $1 \%$ & $3 \%$ & $8 \%$ \\
\hline & From car/van driver to MaaS & $1 \%$ & $5 \%$ & $13 \%$ \\
\hline & From car/van passenger to bicycle & $1 \%$ & $2 \%$ & $5 \%$ \\
\hline & From car/van passenger to motorcycle & $0 \%$ & $1 \%$ & $2 \%$ \\
\hline & From car/van passenger to local bus & $1 \%$ & $5 \%$ & $13 \%$ \\
\hline & From car/van passenger to rail/underground & $1 \%$ & $3 \%$ & $8 \%$ \\
\hline & From car/van passenger to MaaS & $1 \%$ & $3 \%$ & $8 \%$ \\
\hline \multirow[t]{6}{*}{$10-25 \mathrm{mi}$} & From car/van driver to bicycle & $1 \%$ & $2 \%$ & $5 \%$ \\
\hline & From car/van driver to motorcycle & $0 \%$ & $1 \%$ & $2 \%$ \\
\hline & From car/van driver to express coach & $1 \%$ & $5 \%$ & $13 \%$ \\
\hline & From car/van driver to rail/underground & $3 \%$ & $10 \%$ & $25 \%$ \\
\hline & From car/van driver to MaaS & $2 \%$ & $8 \%$ & $20 \%$ \\
\hline & From car/van passenger to bicycle & $0 \%$ & $1 \%$ & $3 \%$ \\
\hline
\end{tabular}


Table 4 (continued)

\begin{tabular}{|c|c|c|c|c|}
\hline Trip length & Mode shift & 2020 & 2030 & 2050 \\
\hline \multirow{10}{*}{$25-50 \mathrm{mi}$} & From car/van passenger to motorcycle & $0 \%$ & $1 \%$ & $2 \%$ \\
\hline & From car/van passenger to express coach & $1 \%$ & $3 \%$ & $8 \%$ \\
\hline & From car/van passenger to rail/underground & $2 \%$ & $10 \%$ & $25 \%$ \\
\hline & From car/van passenger to MaaS & $1 \%$ & $5 \%$ & $13 \%$ \\
\hline & From car/van driver to express coach & $2 \%$ & $10 \%$ & $25 \%$ \\
\hline & From car/van driver to rail/underground & $2 \%$ & $10 \%$ & $25 \%$ \\
\hline & From car/van driver to MaaS & $1 \%$ & $5 \%$ & $13 \%$ \\
\hline & From car/van passenger to express coach & $1 \%$ & $5 \%$ & $13 \%$ \\
\hline & From car/van passenger to rail/underground & $2 \%$ & $10 \%$ & $25 \%$ \\
\hline & From car/van passenger to MaaS & $1 \%$ & $5 \%$ & $13 \%$ \\
\hline \multirow[t]{6}{*}{$50-100 \mathrm{mi}$} & From car/van driver to express coach & $1 \%$ & $5 \%$ & $13 \%$ \\
\hline & From car/van driver to rail/underground & $2 \%$ & $10 \%$ & $25 \%$ \\
\hline & From car/van driver to MaaS & $1 \%$ & $5 \%$ & $13 \%$ \\
\hline & From car/van passenger to express coach & $1 \%$ & $3 \%$ & $8 \%$ \\
\hline & From car/van passenger to rail/underground & $1 \%$ & $5 \%$ & $13 \%$ \\
\hline & From car/van passenger to MaaS & $1 \%$ & $3 \%$ & $8 \%$ \\
\hline \multirow[t]{8}{*}{$>100 \mathrm{mi}$} & From car/van driver to express coach & $1 \%$ & $5 \%$ & $13 \%$ \\
\hline & From car/van driver to rail/underground & $2 \%$ & $10 \%$ & $25 \%$ \\
\hline & From car/van driver to MaaS & $1 \%$ & $5 \%$ & $13 \%$ \\
\hline & From car/van passenger to express coach & $1 \%$ & $3 \%$ & $8 \%$ \\
\hline & From car/van passenger to rail/underground & $1 \%$ & $5 \%$ & $13 \%$ \\
\hline & From car/van passenger to MaaS & $1 \%$ & $3 \%$ & $8 \%$ \\
\hline & From domestic air to express coach & $0 \%$ & $1 \%$ & $5 \%$ \\
\hline & From domestic air to rail/underground & $1 \%$ & $2 \%$ & $9 \%$ \\
\hline
\end{tabular}

MaaS mobility as a service, which includes taxi hailing mobile applications, car clubs and the tendency to hire shared PHEV for longer distance travel

Open Access This article is distributed under the terms of the Creative Commons Attribution 4.0 International License (http:// creativecommons.org/licenses/by/4.0/), which permits unrestricted use, distribution, and reproduction in any medium, provided you give appropriate credit to the original author(s) and the source, provide a link to the Creative Commons license, and indicate if changes were made.

\section{References}

AEA Technology. (2009). Market outlook to 2022 for battery electric vehicles and plug-in hybrid electric vehicles, Final Report to the Committee on Climate Change, ED46299. Didcot: AEA Technology.

Ahmed, A., \& Stopher, P. (2014). Seventy minutes plus or minus 10 - a review of travel time budget studies. Transport
Reviews, 34(5), 607-625. https://doi.org/10.1080 /01441647.2014.946460.

Alam, M. S., \& McNabola, A. (2014).A critical review and assessment of Eco-Driving policy \&amp; technology: Benefits \&amp; limitations Transport Policy, 35(0), 42-49, doi:https://doi.org/10.1016/j.tranpol.2014.05.016

Allen, M. R., Fuglestvedt, J. S., Shine, K. P., Reisinger, A., Pierrehumbert, R. T., \& Forster, P. M. (2016). New use of global warming potentials to compare cumulative and shortlived climate pollutants. [letter]. Nature Clim Change, 6(8), 773-776. https://doi.org/10.1038/nclimate2998.

Anable, J. (2005). 'Complacent Car Addicts' or 'Aspiring Environmentalists'? Identifying travel behaviour segments using attitude theory. Transport Policy, 12(1), 65-78.

Anable, J., Brand, C., Tran, M., \& Eyre, N. (2012). Modelling transport energy demand: a socio-technical approach. Energy Policy, 41, 125-138.

Anderton, K. (2012). Sub-national government responses to reducing the climate impact of cars. Oxford: University of Oxford. 
Banister, D., \& Hickman, R. (2013). Transport futures: thinking the unthinkable. Transport Policy, 29, 283-293. https://doi. org/10.1016/j.tranpol.2012.07.005.

Barth, M., Jugert, P., \& Fritsche, I. (2016). Still underdetectedsocial norms and collective efficacy predict the acceptance of electric vehicles in Germany. Transportation Research Part F: Traffic Psychology and Behaviour, 37, 64-77. https://doi. org/10.1016/j.trf.2015.11.011.

Bates, J. (2000). History of demand modelling. In D. A. Hensher \& K. J. Button (Eds.), Handbook of transport modelling (First ed.). Oxford: Elsevier Science Ltd..

Birtchnell, T., Urry, J., Cook, C., \& Curry, A. (2013). Freight miles: the impacts of $3 \mathrm{D}$ printing on transport and society. Last accessed at http:/ / http://www. academia.edu/3628536/Freight_Miles_The_Impacts of_3D_Printing_on_Transport_and_Society on 05/06 /2017. (pp. 40). Lancaster: University of Lancaster.

Borken-Kleefeld, J., Fuglestvedt, J., \& Berntsen, T. (2013). Mode, load, and specific climate impact from passenger trips. Environmental Science \& Technology, 47(14), 7608-7614. https://doi.org/10.1021/es4003718.

Brand, C. (2010). UK Transport Carbon Model: Reference Guide v1.0, available for download at http://www.ukerc.ac.uk/ programmes/energy-demand/uk-transport-carbonmodel.html. Oxford: UK Energy Research Centre, Energy Demand Theme.

Brand, C. (2016). Beyond 'Dieselgate': implications of unaccounted and future air pollutant emissions and energy use for cars in the United Kingdom. Energy Policy, 97, 1-12. https://doi.org/10.1016/j.enpol.2016.06.036.

Brand, C., Tran, M., \& Anable, J. (2012). The UK transport carbon model: an integrated life cycle approach to explore low carbon futures. Energy Policy, 41, 107-124.

Brand, C., Anable, J., \& Tran, M. (2013). Accelerating the transformation to a low carbon passenger transport system: the role of car purchase taxes, feebates, road taxes and scrappage incentives in the UK. Transportation Research Part A: Policy and Practice, 49(0), 132-148, doi:https://doi.org/10.1016/j. tra.2013.01.010.

Brand, C., Cluzel, C., \& Anable, J. (2017). Modeling the uptake of plug-in vehicles in a heterogeneous car market using a consumer segmentation approach. Transportation Research Part A: Policy and Practice, 97, 121-136. https://doi.org/10.1016 j.tra.2017.01.017.

Cairns, S., Sloman, L., Newson, C., Anable, J., Kirkbride, A., \& Goodwin, P. (2004). Smarter choices - changing the way we travel, Final report of the research project: The influence of soft factor interventions on travel demand. London: Department for Transport (DfT), TSO.

Cairns, S., Sloman, L., Newson, C., Anable, J., Kirkbride, A., \& Goodwin, P. (2008). Smarter choices: Assessing the potential to achieve traffic reduction using 'soft measures'. Transport Reviews, 28, 593-618.

CCC (2013). Fourth carbon budget review-technical report, sectoral analysis of the cost-effective path to the 2050 target. London: Committee on Climate Change (CCC).

CCC (2015). Meeting carbon budgets - progress in reducing the UK's emissions, 2015 report to parliament. London: Committee on Climate Change (CCC).
CCC (2016). Meeting carbon budgets - progress in reducing the UK's emissions, 2016 report to parliament. London: Committee on Climate Change (CCC).

Çelik, H. (2011). Influence of social norms, perceived playfulness and online shopping anxiety on customers' adoption of online retail shopping. International Journal of Retail \& Distribution Management, 39(6), 390-413. https://doi. org/10.1108/09590551111137967.

Chitnis, M., \& Hunt, L. C. (2012). What drives the change in UK household energy expenditure and associated CO2 emissions? Implication and forecast to 2020. Applied Energy, 94(0), 202-214, doi:https://doi.org/10.1016/j. apenergy.2012.01.005.

Cohen, S. A., Higham, J. E. S., \& Cavaliere, C. T. (2011). Binge flying: behavioural addiction and climate change. Annals of Tourism Research, 38(3), 1070-1089. https://doi. org/10.1016/j.annals.2011.01.013.

Cohen, S. A., Duncan, T., \& Thulemark, M. (2013). Introducing lifestyle mobilities. In Lifestyle Mobilities: Intersections of Travel, Leisure and Migration (pp. 1-18).

Creutzig, F. (2015). Evolving narratives of low-carbon futures in transportation. Transport Reviews, 36, 1-20. https://doi. org/10.1080/01441647.2015.1079277.

Creutzig, F., Roy, J., Lamb, W. F., Azevedo, I. M. L., Bruine de Bruin, W., Dalkmann, H., Edelenbosch, O. Y., Geels, F. W., Grubler, A., Hepburn, C., Hertwich, E. G., Khosla, R., Mattauch, L., Minx, J. C., Ramakrishnan, A., Rao, N. D., Steinberger, J. K., Tavoni, M., Ürge-Vorsatz, D., \& Weber, E. U. (2018). Towards demand-side solutions for mitigating climate change. Nature Climate Change, 8(4), 268-271. https://doi.org/10.1038/s41558-018-0121-1.

Crompton, T. (2008). Weathercocks and signposts. The environmental movement at a crossroads. London: WWF.

Daly, H. E., Ramea, K., Chiodi, A., Yeh, S., Gargiulo, M., \& Gallachóir, B. Ó. (2014). Incorporating travel behaviour and travel time into TIMES energy system models. Applied Energy, 135((0)), 429-439. https://doi.org/10.1016/j. apenergy.2014.08.051.

DECC. (2014). Updated energy \& emissions projectionsSeptember 2014, Annex M: Growth assumptions and prices. London: Department of Energy and Climate Change.

Department for Transport (2016). National Travel Survey, 2002-2014: Special Licence access. [data collection]. 4th edition. SN: 7553. UK data service, doi: https://doi.org/10.5255/UKDA-SN-7553-4.

Devlin, S., \& Bernick, S. (2015). Managing aviation passenger demand with a frequent flyer levy. http://hacan.org.uk/wpcontent/uploads/2015/06/FFL-FINAL-DRAFT-intemplate_updated.pdf. Accessed 30/03/2018. London: New Economics Foundation.

DfT. (2014). Transport Statistics Great Britain 2014. London: Department for Transport.

Dodds, P. E., \& McDowall, W. (2014). Methodologies for representing the road transport sector in energy system models. International Journal of Hydrogen Energy, 39(5), 2345-2358. https://doi.org/10.1016/j.ijhydene.2013.11.021.

Dunkerley, F., Rohr, C., \& Daly, A. (2014). Road traffic demand elasticities: A rapid evidence assessment. Last accessed at https://www.rand.org/pubs/research_reports/RR888.html on 05/01/2018. Cambridge: RAND Europe, Crown Copyright. 
ECMT (2006). Cost effectiveness of CO2 mitigation in transport: An outlook and comparison to cost effectiveness of measures in other sectors. Paris: CE for the European Conference of Ministers of Transport (ECMT).

EEA. (2000). COPERT III: Computer Programme to calculate emissions from road transport - methodology and emission factors (version 2.1), technical report no (p. 49). Copenhagen: European Topic Centre on Air and Climate Change, European Environment Agency (EEA).

EEA. (2011). Laying the foundations for greener transportTERM 2011: Transport indicators tracking progress towards environmental targets in Europe. Copenhagen: European Environment Agency.

Ferreira, A., Bertolini, L., \& Næss, P. (2017). Immotility as resilience? A key consideration for transport policy and research. Applied Mobilities, 2(1), 16-31. https://doi. org/10.1080/23800127.2017.1283121.

Fontes, T., \& Pereira, S. R. (2014). Impact assessment of road fleet transitions on emissions: The case study of a medium European size country. Energy Policy, 72, 175-185. https://doi.org/10.1016/j.enpol.2014.04.044.

Geels, F. W., Sovacool, B. K., Schwanen, T., \& Sorrell, S. (2017). Sociotechnical transitions for deep decarbonization. Science, 357(6357), 1242-1244. https://doi.org/10.1126/science. aao3760.

Graham-Rowe, E., Gardner, B., Abraham, C., Skippon, S., Dittmar, H., Hutchins, R., et al. (2012). Mainstream consumers driving plug-in battery-electric and plug-in hybrid electric cars: A qualitative analysis of responses and evaluations. [Article]. Transportation Research Part A: Policy and Practice, 46(1), 140-153. https://doi.org/10.1016/j. tra.2011.09.008.

Gross, R., Heptonstall, P., Anable, J., Greenacre, P., \& E4tech (2009). What policies are effective at reducing carbon emissions from surface passenger transport? A review of interventions to encourage behavioural and technological change, ISBN 190314407 8. London: UK Energy Research Centre.

Hickman, R., \& Banister, D. (2007). Looking over the horizon: Transport and reduced CO2 emissions in the UK by 2030. Transport Policy, 14(5), 377-387.

HM Government. (2017). The clean growth strategy: Leading the way to a low carbon future. London: HM Government.

Ho, S.-H., Wong, Y.-D., \& Chang, V. W.-C. (2015). What can ecodriving do for sustainable road transport? Perspectives from a city (Singapore) eco-driving programme. Sustainable Cities and Society, 14(0), 82-88, doi:https://doi.org/10.1016/j. scs.2014.08.002.

ICCT. (2016). CO2 emissions from new passenger cars in the EU: Car manufacturers' performance in 2015. Berlin: The International Council on Clean Transportation.

IEA (2011). Energy Technology Perspectives 2010, World energy outlook 2011. Paris: International Energy Agency (IEA).

EEA (2012). COPERT 4 (COmputer Programme to calculate Emissions from Road Transport), last accessed at https://emisia.com/content/copert-documentation on 20/02 12018. Copenhagen: European Environment Agency (EEA)

IEA. (2015a). Energy and climate change: World energy outlook special report. Paris: International Energy Agency.

IEA. (2015b). Energy technology perspectives 2015: Mobilising innovation to accelerate climate action. Paris: OECD/IEA.
INFRAS. (2009). Handbook of emission factors for road transport (HBEFA), version 3.1. Bern (CH): INFRAS.

Jones, I., Faulconbridge, J., Marsden, G., \& Anable, J. (2018). Demanding business travel: The evolution of the Timespaces of business practice. In A. Hui, R. Day, \& G. Walker (Eds.), Demanding energy: Space, time and change (pp. 257-277). Cham: Springer International Publishing.

Kay, D., Hill, N., \& Newman, D. (2013). Powering ahead: The future of low-carbon cars and fuels. London: Ricardo-AEA for the RAC Foundation and UKPIA.

Köhler, J., Whitmarsh, L., Nykvist, B., Schilperoord, M., Bergman, N., \& Haxeltine, A. (2009). A transitions model for sustainable mobility. Ecological Economics, 68(12), 2985-2995. https://doi.org/10.1016/j.ecolecon.2009.06.027.

Leinert, S., Daly, H., Hyde, B., \& Gallachóir, B. Ó. (2013). Cobenefits? Not always: Quantifying the negative effect of a $\mathrm{CO} 2$-reducing car taxation policy on NOx emissions. Energy Policy, 63, 1151-1159. https://doi.org/10.1016/j. enpol.2013.09.063.

Li, F. G. N., Trutnevyte, E., \& Strachan, N. (2015). A review of socio-technical energy transition (STET) models. Technological Forecasting and Social Change, 100, 290305. https://doi.org/10.1016/j.techfore.2015.07.017.

Litman, T. (2017). Understanding Transport Demands and Elasticities: How Prices and Other Factors Affect Travel Behavior, last accessed at http://www.vtpi.org/elasticities.pdf on 28/12/2017. Victoria, BC: Victoria Transport Policy Institute.

Luijt, R. S., van den Berge, M. P. F., Willeboordse, H. Y., \& Hoogenraad, J. H. (2017). 5 years of Dutch eco-driving: Managing behavioural change. Transportation Research Part A: Policy and Practice,98, 46-63, doi:https://doi. org/10.1016/j.tra.2017.01.019.

Maione, M., Fowler, D., Monks, P. S., Reis, S., Rudich, Y., Williams, M. L., \& Fuzzi, S. (2016). Air quality and climate change: Designing new win-win policies for Europe. Environmental Science \& Policy, 65, 48-57. https://doi. org/10.1016/j.envsci.2016.03.011.

Mau, P., Eyzaguirre, J., Jaccard, M., Collins-Dodd, C., \& Tiedemann, K. (2008). The 'neighbor effect': Simulating dynamics in consumer preferences for new vehicle technologies. Ecological Economics, 68(1-2), 504-516. https://doi. org/10.1016/j.ecolecon.2008.05.007.

McCollum, D., Yang, C., Yeh, S., \& Ogden, J. (2012). Deep greenhouse gas reduction scenarios for California-strategic implications from the CA-TIMES energy-economic systems model. Energy Strategy Reviews, 1(1), 19-32. https://doi. org/10.1016/j.esr.2011.12.003.

McKinnon, A. C. (2007). Decoupling of road freight transport and economic growth trends in the UK: an exploratory analysis. Transport Reviews, 27, 37-64. https://doi.org/10.1080 /01441640600825952.

Melo, P. C. (2016). Driving down road transport CO2 emissions in Scotland. International Journal of Sustainable Transportation, 10(10), 906-916. https://doi.org/10.1080 /15568318.2016.1176281.

Morganti, E., Seidel, S., Blanquart, C., Dablanc, L., \& Lenz, B. (2014). The impact of E-commerce on final deliveries: alternative parcel delivery Services in France and Germany. Transportation Research Procedia, 4, 178-190. https://doi. org/10.1016/j.trpro.2014.11.014. 
Mullen, C., \& Marsden, G. (2016). Mobility justice in low carbon energy transitions. Energy Research \& Social Science, 18, 109-117. https://doi.org/10.1016/j.erss.2016.03.026.

Mulley, C. (2017). Mobility as a services (MaaS) — does it have critical mass? Transport Reviews, 37(3), 247-251. https://doi.org/10.1080/01441647.2017.1280932.

Nykvist, B., \& Nilsson, M. (2015). Rapidly falling costs of battery packs for electric vehicles. [letter]. Nature Clim. Change, 5(4), 329-332. https://doi.org/10.1038/nclimate2564 http://www.nature.com/nclimate/journal/v $5 / \mathrm{n} 4$ /abs/nclimate2564.html - supplementary-information.

OLEV. (2013). Driving the future today - a strategy for ultra low emission vehicles in the UK. London: Office for Low Emission Vehicles.

Oxley, T., Dore, A. J., ApSimon, H., Hall, J., \& Kryza, M. (2013). Modelling future impacts of air pollution using the multiscale UK integrated assessment model (UKIAM). Environment International, 61, 17-35. https://doi. org/10.1016/j.envint.2013.09.009.

Petrunoff, N., Rissel, C., Wen, L. M., \& Martin, J. (2015). Carrots and sticks vs carrots: comparing approaches to workplace travel plans using disincentives for driving and incentives for active travel. Journal of Transport \& Health, 2(4), 563-567. https://doi.org/10.1016/j.jth.2015.06.007.

Pye, S., \& Daly, H. (2015). Modelling sustainable urban travel in a whole systems energy model. Applied Energy, 159, 97-107. https://doi.org/10.1016/j.apenergy.2015.08.127.

Ritzer, G., \& Jurgenson, N. (2010). Production, consumption, prosumption: the nature of capitalism in the age of the digital 'prosumer'. Journal of Consumer Culture, 10(1), 13-36. https://doi.org/10.1177/1469540509354673.

Rogan, F., Dennehy, E., Daly, H., Howley, M., \& Ó Gallachóir, B. P. (2011). Impacts of an emission based private car taxation policy-first year ex-post analysis. Transportation Research Part A: Policy and Practice, 45(7), 583-597. https://doi. org/10.1016/j.tra.2011.03.007.

Schipper, L. (2011). Automobile use, fuel economy and CO2 emissions in industrialized countries: encouraging trends through 2008? Transport Policy, 18(2), 358-372. https://doi.org/10.1016/j.tranpol.2010.10.011.

Schwanen, T., Banister, D., \& Anable, J. (2011). Scientific research about climate change mitigation in transport: a critical review. Transportation Research Part A: Policy and Practice, 45(10), 993-1006. https://doi.org/10.1016/j. tra.2011.09.005.

Scottish Government (2013a). Going Smarter, Final ReportMonitoring and Evaluation of the Smarter Choices, Smarter Places Programme, last accessed at https://www. transport.gov.scot/media/4811/scsp_- goingsmarter final_version_-_do_not_edit.pdf $\overline{\text { on }}$ 03/12/201 $\overline{6}$. Edinburgh: The Scottish Government.

Scottish Government. (2013b). Low carbon Scotland: Behaviours framework. Edinburgh: Scottish Government.

Scottish Government (2013c). Low carbon Scotland: Meeting our emissions reduction targets 2013-2027. The second report on proposals and policies. Edinburgh: Scottish Government.

Scottish Government. (2015). Cleaner air for Scotland - the road to a healthier future. Edinburgh: The Scottish Government.
Scottish Government. (2017). Draft climate change plan-the draft third report on policies and proposals 2017-2032. Edinburgh: Scottish Government.

Sims, R., Schaeffer, R., Creutzig, F., Cruz-Núñez, X., D’Agosto, M., Dimitriu, D., et al. (2014). Transport. In O. Edenhofer, R. Pichs-Madruga, Y. Sokona, E. Farahani, S. Kadner, K. Seyboth, et al. (Eds.), Climate Change 2014: Mitigation of Climate Change. Contribution of Working Group III to the Fifth Assessment Report of the Intergovernmental Panel on Climate Change. Cambridge, United Kingdom. New York, NY: Cambridge University Press.

Skippon, S. M., Kinnear, N., Lloyd, L., \& Stannard, J. (2016). How experience of use influences mass-market drivers' willingness to consider a battery electric vehicle: a randomised controlled trial. Transportation Research Part A: Policy and Practice, 92, 26-42. https://doi.org/10.1016/j. tra.2016.06.034.

SMMT (2018). UK new car market declines in 2017 but demand still third highest in 10 years, last accessed at https:// www.smmt.co.uk/2018/01/uk-new-car-market-declines2017-demand-still-third-highest-10-years/ on 05/01/2018. Accessed 05/01/2018 2018.

Statistics Netherlands (2016). Transport and mobility 2016. The Hague/Heerlen/Bonaire: Statistics Netherlands.

Suel, E., \& Polak, J. W. (2017). Incorporating online shopping into travel demand modelling: challenges, progress, and opportunities. Transport Reviews, 1-26. https://doi.org/10.1080/01441647.2017.1381864.

Tattini, J., Gargiulo, M., \& Karlsson, K. (2018). Reaching carbon neutral transport sector in Denmark - evidence from the incorporation of modal shift into the TIMES energy system modeling framework. Energy Policy, 113, 571-583. https://doi.org/10.1016/j.enpol.2017.11.013.

Tran, M., Banister, D., Bishop, J. D. K., \& McCulloch, M. D. (2012). Realizing the electric-vehicle revolution. Nature Clim. Change, 2(5), 328-333. https://doi.org/10.1038 /nclimate1429.

Transport Scotland. (2017). Cycling action plan for Scotland 2017-2020. Edinburgh: Transport Scotland.

United Nations (2015). Paris agreement, United Nations framework convention on climate change, COP 21. Paris: United Nations.

Wadud, Z., MacKenzie, D., \& Leiby, P. (2016). Help or hindrance? The travel, energy and carbon impacts of highly automated vehicles. Transportation Research Part A: Policy and Practice, 86, 1-18. https://doi.org/10.1016/j.tra.2015.12.001.

Weber, C., \& Perrels, A. (2000). Modelling lifestyle effects on energy demand and related emissions. Energy Policy, 28(8), 549-566. https://doi.org/10.1016/s0301-4215(00)00040-9.

Yang, C., McCollum, D., McCarthy, R., \& Leighty, W. (2009). Meeting an $80 \%$ reduction in greenhouse gas emissions from transportation by 2050: a case study in California. Transportation Research Part D: Transport and Environment, 14(3), 147-156. https://doi.org/10.1016/j. trd.2008.11.010.

Zimmer, W., Blanck, R., Cyganski, R., Peter, M., Wolfermann, A., \& Mocanu, T. (2017). Renewbility: options for a decarbonisation of the transport sector up to 2050, paper 4 110-17. Paper presented at the eceee 2017 Summer Study, 29 May - 3 June 2017, Giens, France, 